Report of Investigation 2020-2

\title{
REGIONAL TSUNAMI HAZARD ASSESSMENT FOR THE COMMUNITIES OF KASAAN, KLAWOCK, METLAKATLA, PELICAN, POINT BAKER, AND PORT PROTECTION IN SOUTHEAST ALASKA
}

E.N. Suleimani, D.J. Nicolsky, J.B. Salisbury, and M.E. West
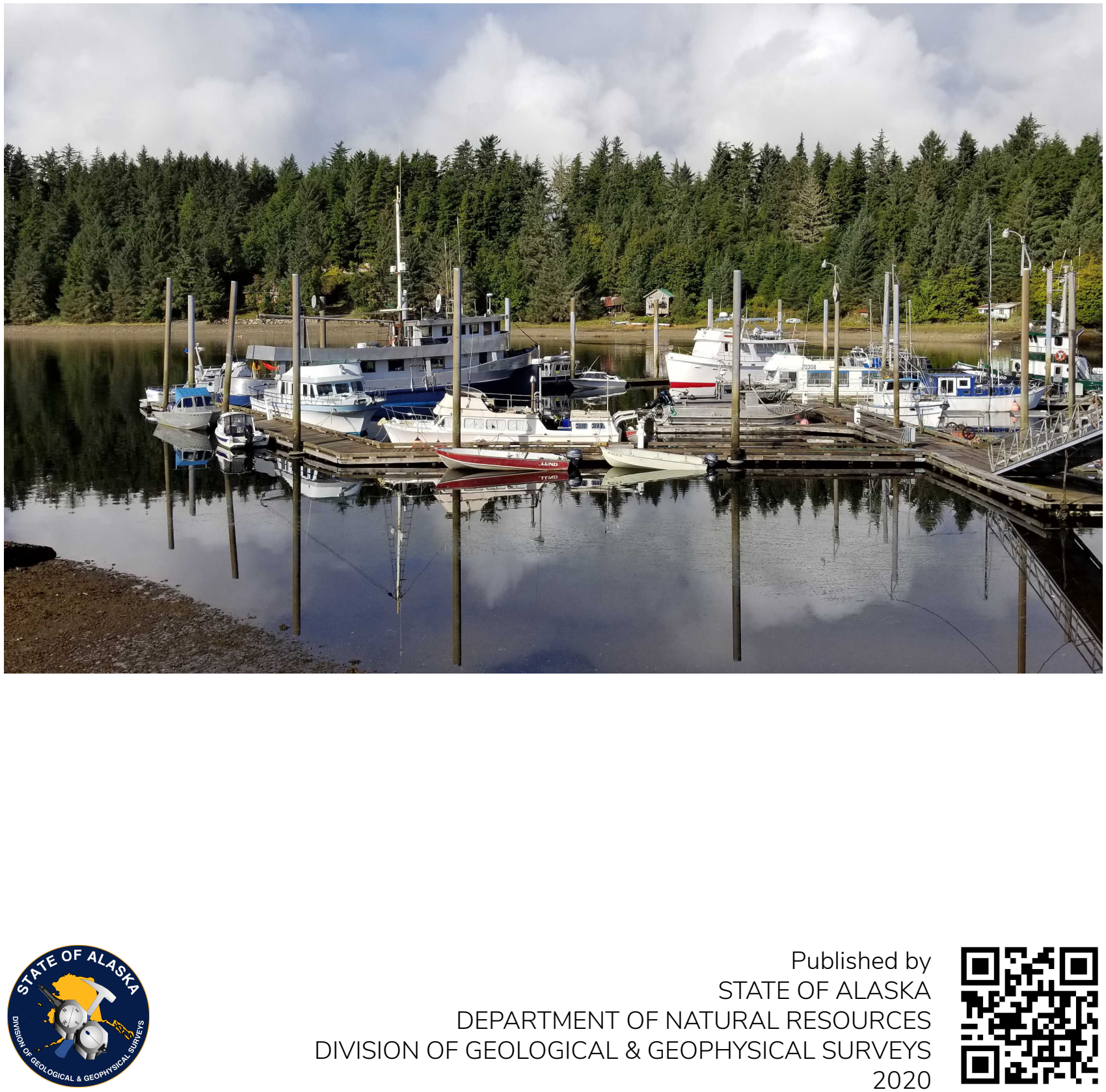

Published by

STATE OF ALASKA

DEPARTMENT OF NATURAL RESOURCES

DIVISION OF GEOLOGICAL \& GEOPHYSICAL SURVEYS 
Cover. View of Klawock harbor in Klawock, Alaska. Photo: Elena Suleimani. 


\title{
REGIONAL TSUNAMI HAZARD ASSESSMENT FOR THE COMMUNITIES OF KASAAN, KLAWOCK, METLAKATLA, PELICAN, POINT BAKER, AND PORT PROTECTION IN SOUTHEAST ALASKA
}

\author{
E.N. Suleimani, D.J. Nicolsky, J.B. Salisbury, and M.E. West
}

Report of Investigation 2020-2

State of Alaska

Department of Natural Resources

Division of Geological \& Geophysical Surveys 


\section{STATE OF ALASKA}

Mike Dunleavy, Governor

\section{DEPARTMENT OF NATURAL RESOURCES}

Corri A. Feige, Commissioner

\section{DIVISION OF GEOLOGICAL \& GEOPHYSICAL SURVEYS}

Steve Masterman, State Geologist and Director

Publications produced by the Division of Geological \&

Geophysical Surveys (DGGS) are available for free download

from the DGGS website (dggs.alaska.gov). Publications on

hard-copy or digital media can be examined or purchased in

the Fairbanks office:

Alaska Division of Geological \& Geophysical Surveys

3354 College Rd., Fairbanks, Alaska 99709-3707

Phone: (907) 451-5010 Fax (907) 451-5050

dggspubs@alaska.gov|dggs.alaska.gov

\section{DGGS publications are also available at:}

Alaska State Library,

Historical Collections \& Talking Book Center

395 Whittier Street

Juneau, Alaska 99811

Alaska Resource Library and Information Services (ARLIS)

3150 C Street, Suite 100

Anchorage, Alaska 99503

\section{Suggested citation:}

Suleimani, E.N., Nicolsky, D.J., Salisbury, J.B., and West, M.E., 2020, Regional tsunami hazard assessment for the communities of Kasaan, Klawock, Metlakatla, Pelican, Point Baker, and Port Protection in Southeast Alaska: Alaska Division of Geological \& Geophysical Surveys Report of Investigation 2020-2, 24 p., 6 sheets. doi.org/10.14509/30423
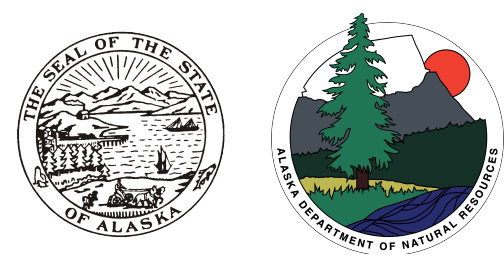


\section{Contents}

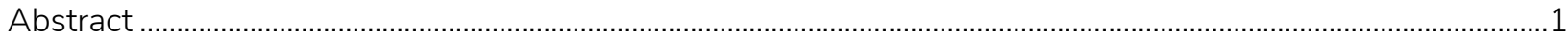

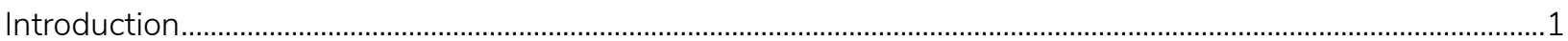

Project background: Regional and Historical Context..........................................................................................2

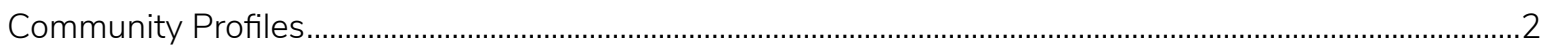

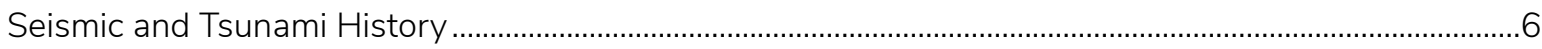

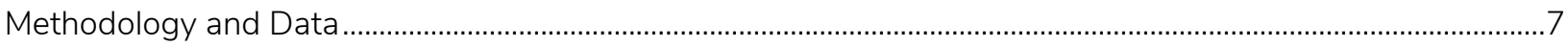

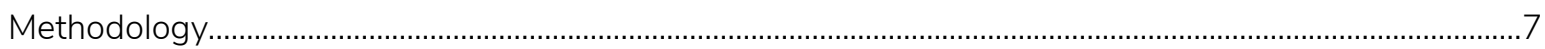

Computational Grids and Data Sources ......................................................................................................

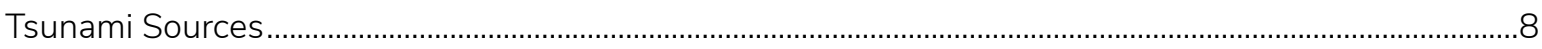

$M_{\mathrm{W}} 9.3$ event: Extended 1964 rupture ........................................................................................ 10

$M_{W} 9.2$ event: Earthquake in the 1964 rupture area with Tohoku-type slip distribution ............10

$M_{W} 9.0$ event: The SAFRR tsunami scenario ..................................................................................... 10

$M_{W} 9.0$ event: Rupture of the Cascadia subduction zone

Numerical Model of Tsunami Propagation and Runup ................................................................................

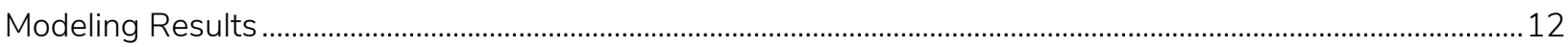

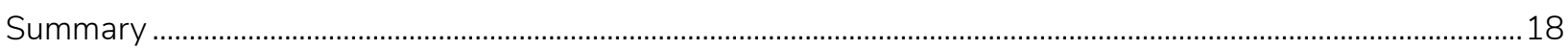

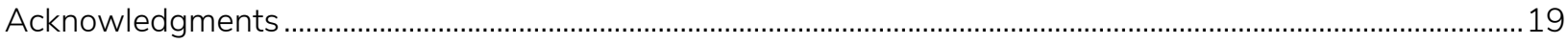

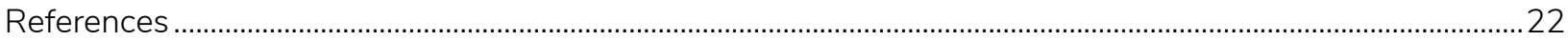

\section{Figures}

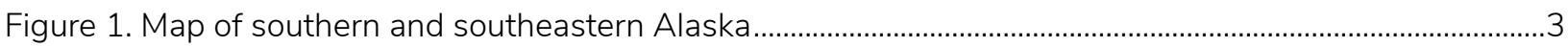

Figure 2. Maps showing the locations of the communities in this study .................................................................

Figure 3. Nested bathymetry/topography grids for numerical modeling of tsunami

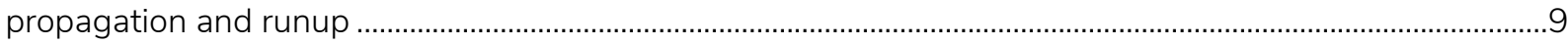

Figure 4. Vertical coseismic deformations corresponding to scenarios 1-4 .....................................................11

Figure 5. Maximum composite tsunami height from all scenarios in the Cross Sound level 3 grid.................12

Figure 6. Maximum composite tsunami height from all scenarios in the Prince of Wales level 3 grid............13

Figure 7. Maximum composite tsunami heights at the communities in this study............................................ 14

Figure 8. Time series of water level for scenarios 1-4 .......................................................................................

\section{Tables}

Table 1. Tsunami effects from all historically recorded tsunamis at Klawock, Pelican, and Metlakatla .............6

Table 2. Nested grids used to compute propagation of tsunami waves from nearby subduction zones to the communities in this study

\section{Map Sheets}

Sheet 1. Tsunami hazard map for Kasaan, Alaska

Sheet 2. Tsunami hazard map for Klawock, Alaska

Sheet 3. Tsunami hazard map for Metlakatla, Alaska

Sheet 4. Tsunami hazard map for Pelican, Alaska

Sheet 5. Tsunami hazard map for Point Baker, Alaska

Sheet 6. Tsunami hazard map for Port Protection, Alaska 



\title{
REGIONAL TSUNAMI HAZARD ASSESSMENT FOR THE COMMUNITIES OF KASAAN, KLAWOCK, METLAKATLA, PELICAN, POINT BAKER, AND PORT PROTECTION IN SOUTHEAST ALASKA
}

\author{
E.N. Suleimani ${ }^{1}$, D.J. Nicolsky ${ }^{1}$, J.B. Salisbury², and M.E. West ${ }^{1}$
}

\begin{abstract}
We assess potential tsunami hazards for six communities in Southeast Alaska: Kasaan, Klawock, Metlakatla, Pelican, Point Baker, and Port Protection. These communities have no high-resolution bathymetry or topography, therefore we conduct tsunami hazard assessments for these areas at the regional scale. The regional approach is a suitable, costeffective approximation and replacement for high-resolution tsunami inundation maps. The primary tsunami hazard considered for these communities originates from tsunamigenic earthquakes along the Alaska-Aleutian subduction zone across the Gulf of Alaska. We numerically model tsunami waves generated by four different megathrust earthquakes and develop approximate tsunami hazard maps for the six communities. The hypothetical tsunami scenarios that we examined include variations of an extended 1964 rupture, megathrust earthquakes in the Prince William Sound and Alaska Peninsula regions, and a Cascadia megathrust earthquake. We do not include impacts of subaerial or submarine landslide tsunami sources, as that is beyond the scope of this study. The maximum runup heights from tectonically-generated tsunamis are $1.4 \mathrm{~m}(4.6 \mathrm{ft})$ in Kasaan, $4 \mathrm{~m}(13 \mathrm{ft})$ in

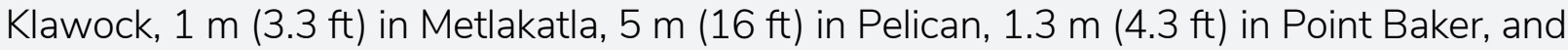
$2.6 \mathrm{~m}(8.5 \mathrm{ft})$ in Port Protection. Results presented here are intended to provide guidance to local emergency management agencies in initial tsunami inundation assessment, evacuation planning, and public education for mitigation of future tsunami hazards.
\end{abstract}

\section{INTRODUCTION}

Tsunami hazards along Alaska's Pacific coastline are widespread. Virtually all of Alaska's southern and southeastern coasts are defined by major offshore fault systems. Unlike tsunamis that are caused by distant earthquakes on the other side of the Pacific, Alaska's greatest tsunami hazards originate just offshore and can inundate coastlines within an hour of a causative earthquake. This reduces the time available to respond and evacuate and can produce drastically higher wave heights than far-traveled tsunamis. Because many Alaska communities hug the shoreline (due to some combination of steep mountains, dense forests, and/or reliance on the open water for transportation), they are within the tsunami inundation zone and are at risk of rapid flooding. In addition to earthquake-generated (i.e., tectonic) tsunamis, mass movements of sediments down slopes (either on land or in the ocean) can also generate tsunamis. While rapid tsunami flooding is the immediate concern after a large coastal earthquake, dangerous (potentially disastrous) near-shore ocean currents and permanent changes to the local coastline are additional concerns.

\footnotetext{
${ }^{1}$ Alaska Earthquake Center, Geophysical Institute, University of Alaska, P.O. Box 757320, Fairbanks, Alaska 99775-7320; ensuleimani@alaska.edu

2Alaska Division of Geological \& Geophysical Surveys, 3354 College Rd., Fairbanks, Alaska 99709-3707.
} 
The local, tectonic tsunami danger to communities in southeast Alaska comes primarily from two fault systems that span the entire southern and southeastern coasts of Alaska (Carver and Plafker, 2008) (fig. 1). The Alaska-Aleutian subduction zone spans from the westernmost Aleutian Islands to the Gulf of Alaska. This subduction zone represents the collision between the Pacific plate to the south and the North American plate to the north. Relative to the North American plate, the Pacific Plate is moving northwest at approximately $5-8 \mathrm{~cm}(2-3$ inches) per year, colliding with the North American plate and diving beneath it in a process known as subduction (Freymueller and others, 2008). East of the subduction zone the fault orientation and style of deformation changes. The second major fault system begins in the Gulf of Alaska and extends more than $1,000 \mathrm{~km}$ southeast along the Alaska and Canadian coastlines, known as the Fairweather and Queen Charlotte faults, respectively. The Fairweather-Queen Charlotte (F-QC) fault system primarily accommodates right lateral strikeslip (i.e., side-to-side) motion between the Pacific and North American plates.

The specifics of tsunami hazards are particular to each community and vary considerably over large regions. The shape of the coastline, local bathymetry, and topography all affect tsunami impacts. More importantly, however, is the earthquake source (the location, magnitude, and style) being considered and the community's location relative to that earthquake. For subduction zone earthquakes, communities in Southeast Alaska can generally expect a tsunami crossing the Gulf of Alaska to take an hour or more to reach their shores. Earthquakes along the F-QC system pose a much more immediate tsunami threat, with travel times measured in minutes instead of hours. Fortunately, strike-slip earthquakes (those characteristic of the F-QC system) do not typically deform the seafloor vertically and therefore are less likely to produce significant tsunamis. However, strong earthquake shaking in Southeast Alaska may cause landslides, either from steep fjord cliffs or underwater slopes, that generate locally significant tsunamis. We do not address any landslide-generated tsunamis in this report.

The impacts of future earthquakes and tsunamis can be reduced if citizens, emergency managers, and city planners take steps to mitigate the hazards. This report is intended to support hazard mitigation efforts by providing approximate tsunami hazard estimates for the communities of Kasaan, Klawock, Metlakatla, Pelican, Point Baker, and Port Protection. The scenario earthquakes, numerical tsunami models, and resulting maps are developed on a regional level and lack the precision of studies that are fully tailored to individual communities (e.g., Nicolsky and others, 2013, 2014; Suleimani and others, 2013, 2015). The current study is based on just four scenario earthquakes. Even so, the results provide a good first approximation of tsunami hazard. The maps, documentation, and available digital data provide a foundation for public education, support the development of evacuation procedures, and provide insights intended to improve community resilience.

\section{PROJECT BACKGROUND: REGIONAL AND HISTORICAL CONTEXT}

\section{Community Profiles}

The following information is extracted from the Alaska Community Database Online provided by the State of Alaska Division of Community and Regional Affairs (dcra-cdo-dcced.opendata.arcgis. $\mathrm{com} /$ ). Maps showing locations of communities in Southeast Alaska are presented in figure 2. Refer to figure 1 for locations of figures $2 \mathrm{~A}$ and $2 \mathrm{~B}$.

Kasaan, population 80 , is one of two Haida villages in Alaska, and is located on the east side of Prince of Wales (POW) Island on Kasaan Bay off the Clarence Strait (fig. 2A). The village is spread along approximately $3.2 \mathrm{~km}$ (2 mi) of low-lying, forested land, although much of the surrounding land has been logged in recent years. Kasaan is accessed by boat or sea plane, and is also connected 


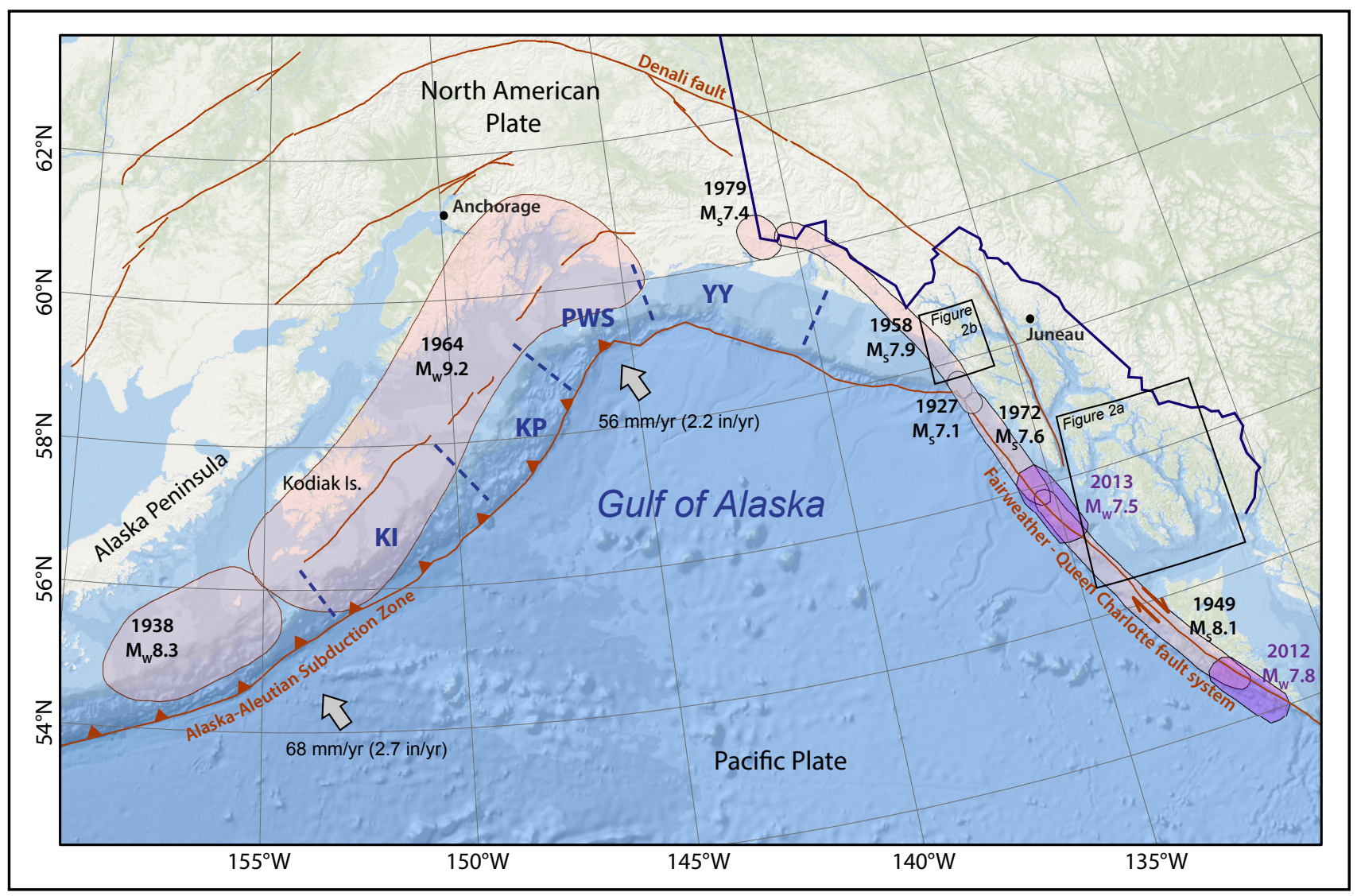

Figure 1. Map of southern and southeastern Alaska. The rupture areas of significant earthquakes are shown by pink polygons. The most recent earthquakes of 2012 and 2013 are shown by purple polygons. Black polygons outline the areas shown in figures 2A and 2B. The dashed blue lines indicate the Kodiak Island (KI), Kenai Peninsula (KP), Prince William Sound (PWS), and Yakataga-Yakutat (YY) segments of the Alaska-Aleutian subduction zone.

to the POW road system via a $27.4-\mathrm{km}$ (17-mile) gravel road. The population is a mix of Native and non-Native residents, and subsistence activities are a significant part of the local culture.

Klawock, population 883, is a mixed Tlingit and non-Native community located on the central western coast of POW Island (fig. 2A). Klawock is at the "crossroads" of the island where the paved highways intersect, leading south to Craig, east to Hollis and the ferry terminal, and northeast to the communities on the northern half of the island. Klawock hosts the only airstrip on POW Island $(1,524 \mathrm{~m}[5,000 \mathrm{ft}]$ paved runway) and is heavily reliant on air transportation from Ketchikan. There is also a boat harbor, boat launch ramp, and state-operated seaplane base. A deep draft dock is located at Klawock Island, which is primarily used for loading timber. Most residents pursue a subsistence lifestyle to provide food sources.

Metlakatla, population 1,422 , is located on the central western coast of Annette Island, $25.7 \mathrm{~km}$ (16 mi) south of Ketchikan (fig. 2A). It is accessible by air and water, and hosts an airport with two asphalt runways $9.7 \mathrm{~km}(6 \mathrm{mi})$ south of town. There are also two seaplane bases with scheduled float plane services to and from Ketchikan. The state ferry serves Metlakatla from Ketchikan between spring and fall. In addition to the state ferry terminal, extensive port facilities in Metlakatla include an oil company pier, a city pier, a packing company wharf, a barge terminal, a barge ramp, two marine railways for hauling out boats, and public and privately owned small-craft facilities including two small boat harbors. Most 
infrastructure in Metlakatla is at or very near sea level. The community is traditional Tsimshian with an active economy and subsistence lifestyle. It is located within the Annette Island Reserve, which is the only Indian reservation in Alaska.
Port Protection, population 34, is a small non-Native fishing community on the northern tip of Prince of Wales Island $233.4 \mathrm{~km}(145 \mathrm{mi})$ south of Juneau (fig. 2A). On the north shore of Sumner Strait, it is almost hidden amongst the trees of the

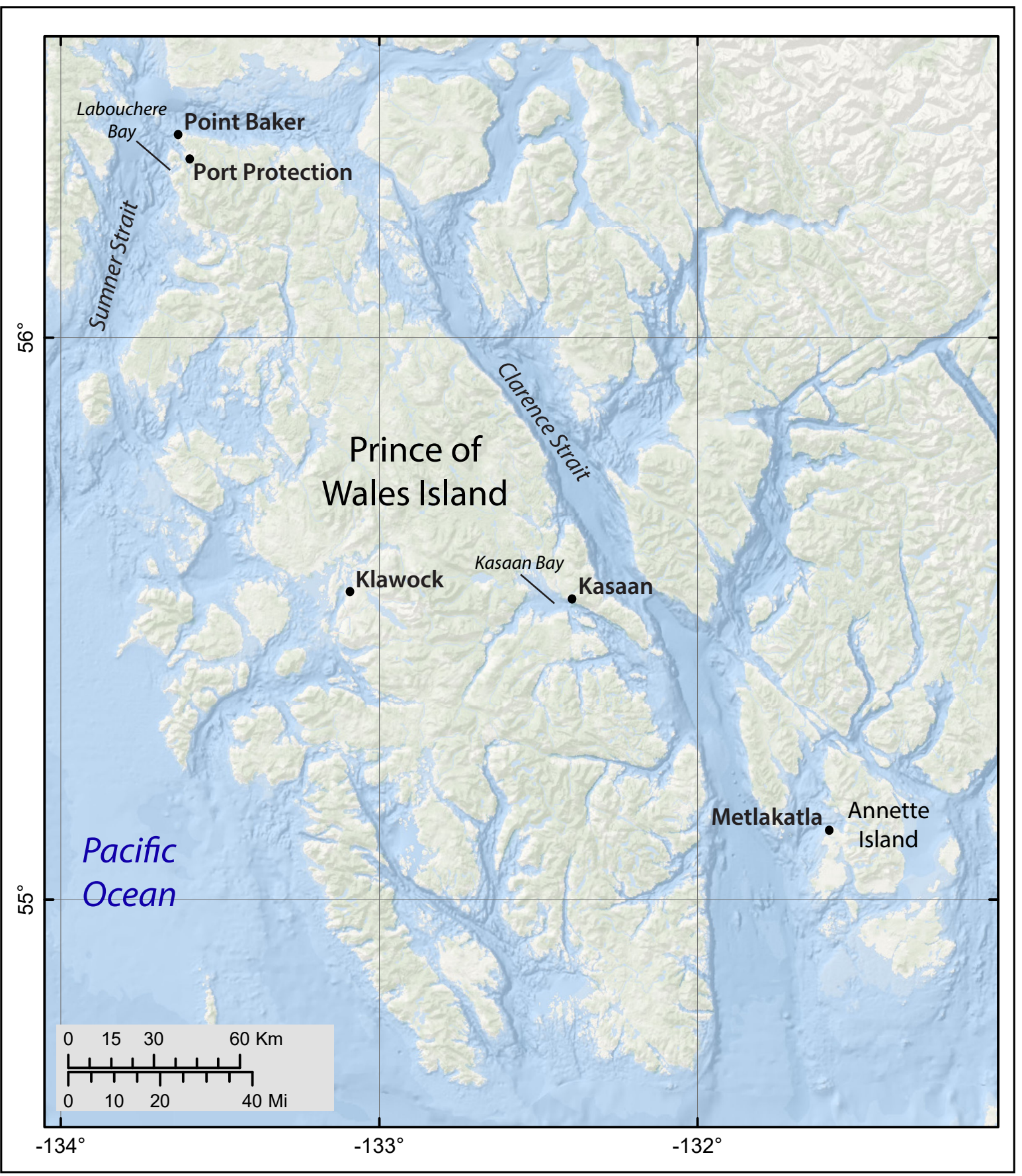

Figure 2A. The locations of Kasaan, Klawock, Metlakatla, Point Baker, and Port Protection on the Prince of Wales Island region of Southeast Alaska. 
Tongass National Forest. It is accessed by float plane and boat and does not link directly to the Prince of Wales road system, although a gravel boat launch at Labouchere Bay, a little more than a mile from the community, provides road access. Skiffs are used for local travel, and there is a boat harbor and launch ramp. Most homes are along the waterfront.

Point Baker, population 13, is a small non-Native fishing community located about 4.8 $\mathrm{km}(3 \mathrm{mi})$ to the north along the coast from Port Protection on the northern tip of Prince of Wales Island (fig. 2A). It does not link to the Prince of Wales road system, and is accessed only by float plane, helicopter, barge, or skiff. A 134.1-m (440$\mathrm{ft}$ ) state-owned floating dock is the "floating down- town” and includes a floatplane dock, store, café, saloon, community building, post office, and fire department. Two seasonal fishing and wildlife viewing lodges are also located on the waterfront, flanked on all sides by the trees and thick vegetation of the Tongass National Forest.

Pelican, population 67, is located on the northwest coast of Chichagof Island on the north shore of Lisianski Inlet, $112.7 \mathrm{~km}$ (70 mi) west-southwest of Juneau (fig. 2B). Most of the community is built on pilings over the tidelands. Pelican is accessed by boat or float plane. Facilities include a state ferry terminal and sea plane dock. During winter months, fog, high winds, and high seas can limit access. There are no paved roads in Pelican, and a

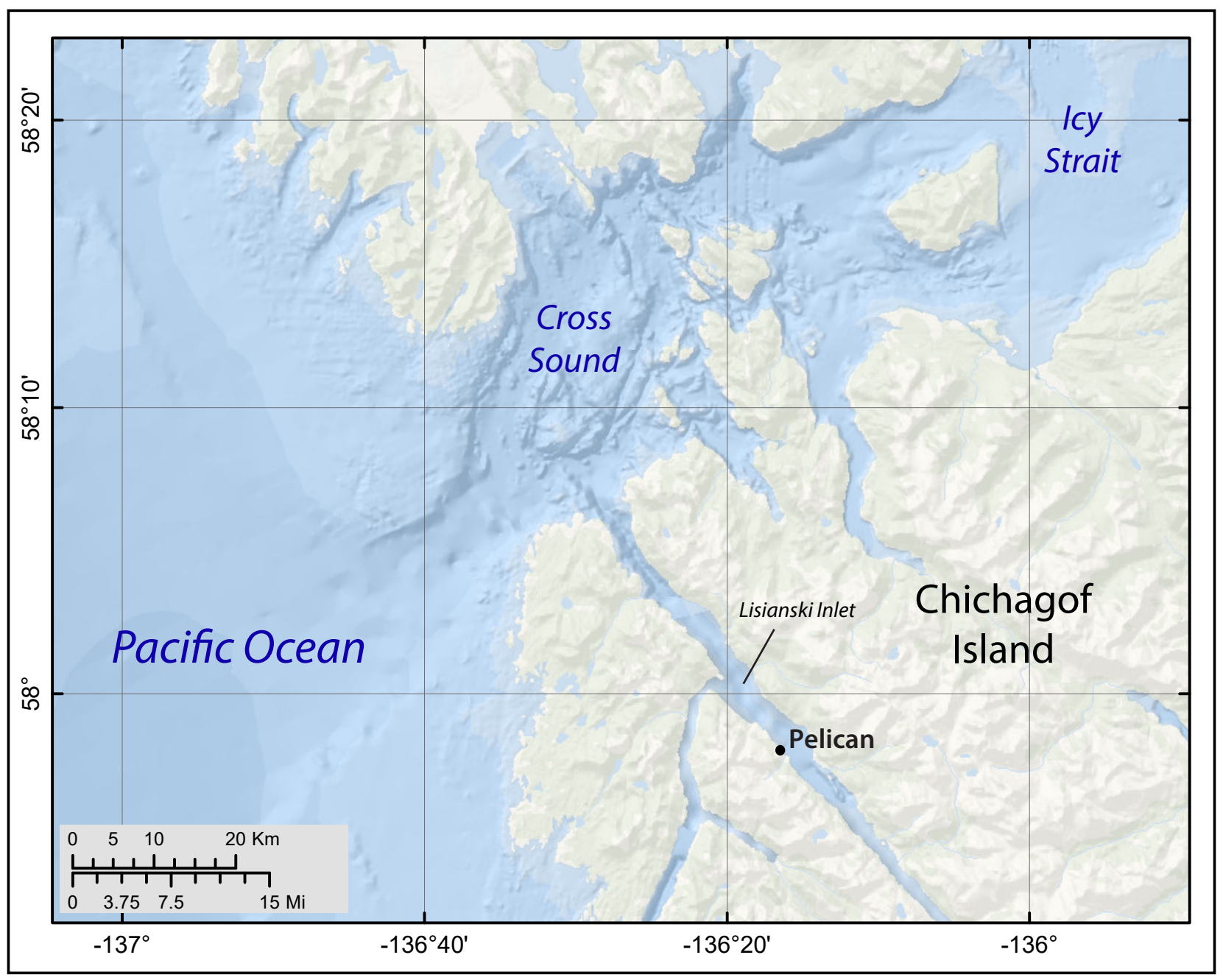

Figure 2B. The location of Pelican in the Cross Sound region of Southeast Alaska. 
boardwalk serves as the town's main thoroughfare due to the lack of flat land. Pelican remains a fishing community, although the fish processing plant closed in 2009. Most residents rely on subsistence resources as an important part of their lifestyle.

\section{Seismic and Tsunami History}

Historic and geologic records of earthquakes and tsunamis in these Southeast Alaska communities are dominated by the great $(M>8)$ earthquakes of the Alaska-Aleutian subduction zone (Dunbar and Weaver, 2008). Several historic megathrust earthquakes have caused tsunamis resulting in widespread damage and loss of life in Alaska and throughout the Pacific (Lander, 1996) (table 1). The latest sequence of great megathrust earthquakes (Carver and Plafker, 2008) appears to have begun in 1938 with a $\mathrm{M}_{\mathrm{W}} 8.3$ earthquake west of Kodiak Island (Estabrook and others, 1994). Four subsequent events, the $1946 \mathrm{M}_{\mathrm{W}}$ 8.6 Eastern Aleutian (Lopez and Okal, 2006), the $1957 \mathrm{M}_{\mathrm{W}} 8.6$ Andreanof Islands (Johnson and others, 1994), the $1964 \mathrm{M}_{\mathrm{W}} 9.2$ Great Alaska (Kanamori, 1970), and the $1965 \mathrm{M}_{\mathrm{W}} 8.7$ Rat Island (Wu and Kanamori, 1973) earthquakes, ruptured much of the length of the subduction zone (fig. 1).
The 1946 Eastern Aleutian Islands earthquake killed 159 people in Hawaii and caused \$26 million in damage (Lopez and Okal, 2006). The earthquake was the impetus for founding the Pacific Tsunami Warning Center in Hawaii. The $1964 \mathrm{M}_{\mathrm{W}} 9.2$ Great Alaska Earthquake devastated communities across Alaska's southern coast. The tsunami from this event killed 106 people in Alaska, most of them resulting from local landslide-generated tsunamis. The tectonic tsunami killed an additional 12 people in California (Lander, 1996) and was the impetus for establishing the Alaska/ West Coast Tsunami Warning Center. The tsunami struck many communities in southeast Alaska, causing varying degrees of damage, but no lives were lost there (Lander, 1996).

The Fairweather-Queen Charlotte fault system that parallels the Southeast Alaska coastline also has a long history of producing large earthquakes. Most of the fault system has ruptured in large strike-slip earthquakes over the past century: $1927\left(\mathrm{M}_{s} 7.1\right)$, $1949\left(\mathrm{M}_{s} 8.1\right), 1958\left(\mathrm{M}_{s} 7.9\right)$, and $1972\left(\mathrm{M}_{s} 7.6\right)$ (Page, 1973; Sykes, 1971; Tocher, 1960) (fig. 1). Several of these earthquakes generated tsunamis. The 1958 earthquake triggered a large landslide into

Table 1. Tsunami effects from all historically recorded tsunamis at Klawock, Pelican, and Metlakatla (no data have been recorded for Point Baker, Port Protection, or Kasaan). Data from the National Centers for Environmental Information (NCEl; formerly known as National Geophysical Data Center [NGDC]) Global Historical Tsunami Database (doi.org/10/7289/V5PN93H7) and comments from Lander (1996).

\begin{tabular}{|c|c|c|c|c|}
\hline Date & $\begin{array}{l}\text { Magnitude } \\
\left(\mathrm{M}_{\mathrm{w}}\right)\end{array}$ & Origin & $\begin{array}{c}\text { Maximum } \\
\text { water height } \\
(\mathrm{m})\end{array}$ & Comments \\
\hline \multicolumn{5}{|c|}{ Klawock } \\
\hline 03/28/1964 & 9.2 & Gulf of Alaska & 4.6 & 3 houses lost \\
\hline \multicolumn{5}{|c|}{ Pelican } \\
\hline 03/28/1964 & 9.2 & Gulf of Alaska & Observed & $\begin{array}{l}\text { Home flooded, boardwalk warped, } \\
\text { and } 2 \text { scows broken loose. }\end{array}$ \\
\hline \multicolumn{5}{|c|}{ Metlakatla (Annette Island) } \\
\hline 03/28/1964 & 9.2 & Gulf of Alaska & 1.2 & \\
\hline
\end{tabular}


Lituya Bay that generated a 530-m-high $(1,740-\mathrm{ft}-$ high) wave (Miller, 1960). The 2012 Haida Gwaii earthquake occurred along a convergent section of the Queen Charlotte fault (Lay and others, 2013; James and others, 2013). Uplift of the seafloor during the Haida Gwaii earthquake generated a tsunami that exceeded $6 \mathrm{~m}(20 \mathrm{ft})$ of runup at a number of sites, and measured $0.8 \mathrm{~m}(2.6 \mathrm{ft})$ at a tide gauge in Hawaii (Leonard and Bednarski, 2015). The most recent large earthquake on the F-QC system, the January 5, $2013 \mathrm{M}_{\mathrm{W}} 7.5$ Craig earthquake, produced only modest local tsunamis but was sufficient to initiate tsunami evacuations in several communities (NOAA/NWS, n.d.).

\section{METHODOLOGY AND DATA Methodology}

In recent years, similar tsunami hazard studies have been published for Adak, Atka, False Pass, Perryville, Craig, and several other coastal communities. Because the currently available elevation data for the six southeast Alaska communities in this study are of insufficient quality for high-resolution modeling, we follow the National Tsunami Hazard Mitigation Program (NTHMP, 2010) guidelines (nws.weather.gov/nthmp/documents/3nonmodeledregionguidelines.pdf) for determining tsunami hazard zones for areas that have either low risk due to small population size and minimal infrastructure vulnerability, or do not have access to high-resolution topographic/bathymetric data. The tsunami hazard maps of Kasaan, Klawock, Metlakatla, Pelican, Point Baker, and Port Protection are developed using the methodology described in detail in Suleimani and others (2018). For the four scenario earthquakes we model water dynamics from source to community and compute maximum tsunami wave heights using the highest resolution grids available (see table 2). Each model run covers 24 hours of post-earthquake tsunami propagation to account for all waves in the wave train, as well as secondary (reflected) wave interactions. At every location throughout the high-resolution grids, the maximum tsunami height from any of the four

Table 2. Nested grids used to compute propagation of tsunami waves from nearby subduction zones to the communities of Port Protection, Point Baker, Pelican, Klawock, Metlakatla, and Kasaan. The high resolution grid is used to compute the inundation. Note that the grid resolution in meters is not uniform: the first dimension is the longitudinal grid resolution and the second is the latitudinal resolution. Measurements also vary across each grid and are given for a reference location near Price of Wales Island to illustrate relative grid fineness.

\begin{tabular}{|c|c|c|c|c|}
\hline \multirow[b]{2}{*}{ Grid name } & \multicolumn{2}{|c|}{ Resolution } & \multirow[b]{2}{*}{$\begin{array}{l}\text { East-West } \\
\text { boundaries }\end{array}$} & \multirow[b]{2}{*}{$\begin{array}{l}\text { North-South } \\
\text { boundaries }\end{array}$} \\
\hline & $\begin{array}{c}\text { arc- } \\
\text { seconds }\end{array}$ & $\begin{array}{c}\text { meters } \\
\text { (near POW } \\
\text { Island) }\end{array}$ & & \\
\hline $\begin{array}{l}\text { Level 0, Northern } \\
\text { Pacific }\end{array}$ & $120 \times 120$ & $\approx 2,110 \times 3,704$ & $120^{\circ} 00^{\prime} \mathrm{E}-100^{\circ} 00^{\prime} \mathrm{W}$ & $10^{\circ} 00^{\prime} \mathrm{N}-65^{\circ} 00^{\prime} \mathrm{N}$ \\
\hline $\begin{array}{l}\text { Level 1, Southeast } \\
\text { Alaska }\end{array}$ & $24 \times 24$ & $\approx 421 \times 741$ & $142^{\circ} 00^{\prime} \mathrm{W}-131^{\circ} 00^{\prime} \mathrm{W}$ & $54^{\circ} 00^{\prime} \mathrm{N}-60^{\circ} 00^{\prime} \mathrm{N}$ \\
\hline $\begin{array}{l}\text { Level 2, Coarse } \\
\text { resolution, Juneau West }\end{array}$ & $8 \times 8$ & $\approx 140 \times 247$ & $138^{\circ} 16^{\prime} 08^{\prime \prime} \mathrm{W}-134^{\circ} 15^{\prime} 52^{\prime \prime} \mathrm{W}$ & $55^{\circ} 44^{\prime} 52^{\prime \prime} N-59^{\circ} 33^{\prime} 08^{\prime \prime} N$ \\
\hline $\begin{array}{l}\text { Level 2, Coarse } \\
\text { resolution, Juneau East }\end{array}$ & $8 \times 8$ & $\approx 140 \times 247$ & $135^{\circ} 48^{\prime} 56^{\prime \prime} \mathrm{W}-131^{\circ} 49^{\prime} 04^{\prime \prime} \mathrm{W}$ & $54^{\circ} 36^{\prime} 04^{\prime \prime} N-57^{\circ} 35^{\prime} 56^{\prime \prime} N$ \\
\hline $\begin{array}{l}\text { Level 3, Fine resolution, } \\
\text { Cross Sound }\end{array}$ & $3 \times 3$ & $\approx 47 \times 82$ & $138^{\circ} 08^{\prime} 43^{\prime \prime} \mathrm{W}-137^{\circ} 01^{\prime} 33^{\prime \prime} \mathrm{W}$ & $57^{\circ} 48^{\prime} 57^{\prime \prime} N-58^{\circ} 27^{\prime} 19^{\prime \prime} N$ \\
\hline $\begin{array}{l}\text { Level 3, Fine resolution, } \\
\text { Prince of Wales Island }\end{array}$ & $3 \times 3$ & $\approx 47 \times 82$ & $135^{\circ} 00^{\prime} 11^{\prime \prime} \mathrm{W}-132^{\circ} 01^{\prime} 49^{\prime \prime} \mathrm{W}$ & $54^{\circ} 38^{\prime} 17^{\prime \prime} N-56^{\circ} 38^{\prime} 39^{\prime \prime} N$ \\
\hline
\end{tabular}


earthquakes is saved, and we use these maximum values to generate a new, "composite" map of maximum wave heights that can be expected from the earthquake scenarios.

\section{Computational Grids and Data Sources}

We model tsunami waves and inundation using a series of nested computational grids. A nested grid allows for higher-resolution computations in areas where detail is needed while minimizing computer runtime in areas where such detail is not required. The bathymetric and topographic relief in each nested grid is based on digital elevation models (DEMs) developed at the National Centers for Environmental Information (NCEI) of the National Oceanic and Atmospheric Administration (NOAA) in Boulder, Colorado. The extent of each grid used in this mapping project is shown in figure 3 and listed in table 2. The coarsest grid (level 0), with 2-arc-minute resolution, spans the central and northern Pacific Ocean. The bathymetric data for the 2-arc-minute-resolution grid is extracted from the ETOPO2 dataset (NGDC, 2006, doi.org/10.7289/V5J1012Q). We use two intermediate grids between the coarsest- and highest-resolution grids (table 2). To develop 8/3-, 8 -, and 24-arc-second resolution grids, shoreline, bathymetric, and topographic digital datasets were obtained from several U.S. federal and academic agencies, including: NOAA's National Ocean Service, Office of Coast Survey, NGDC, the U.S. Fish \& Wildlife Service, the U.S. Geological Survey (USGS), and the U.S. Army Corps of Engineers. All data were shifted to World Geodetic System 1984 (WGS 84) horizontal and Mean Higher High Water (MHHW) vertical datums. The data sources and methodology used to create the 24-, 8-, and 8/3-arc-second DEMs are described in greater detail in Caldwell and others (2012) and Lim and others (2011).

One fine-resolution level 3 grid covers Pelican. A second level 3 grid covers the remaining communities. The size of the fine-resolution grid cells, which is $-45 \times 82 \mathrm{~m}(148 \times 269 \mathrm{ft})$, satisfies NOAA's minimum recommended requirements for estimation of the tsunami hazard zone (NTHMP, 2010); however, we did not use on-site GPS methods to verify the level 3 fine-resolution grids (this is particularly important for the intertidal and near-shore zones). Because of this, we do not include the highest-resolution modeling in this report. Instead we provide an estimation of the tsunami hazard zone by extrapolating the maximum composite tsunami wave height onto land according to the tsunami scenarios described below. We account for uncertainties inherent in this method by applying a safety scaling factor of 30 percent to the estimated hazard zone.

\section{Tsunami Sources}

We use a deterministic approach for our earthquake and tsunami hazard modeling. We define the largest hypothetical, yet scientifically-defendable, earthquake scenarios that could affect the communities and calculate the potential resulting tsunami inundation. Although we do not explicitly develop the "worst-case" scenarios for each community, we develop our earthquake sources based on previous studies focused on maximum credible scenarios for coastal Alaska. For this study, we use three great earthquakes in the eastern part of the Alaska-Aleutian subduction zone that have been published in previous studies (Suleimani and others, 2013, 2015, 2016), as well as a rupture of the Cascadia subduction zone (Ross and others, 2013). This approach is drastically different from probabilistic hazard analyses used for land-use planning or insurance estimates (Geist and Parsons, 2006). Probabilistic earthquake hazards consider all possible earthquakes (both large and small) and define the probability that an earthquake of a certain magnitude will occur in a given amount of time.

Below we describe the significant credible tsunami sources for the six Southeast communities. The vertical coseismic deformations for these scenarios are shown in figure $4 \mathrm{~A}-\mathrm{D}$. 


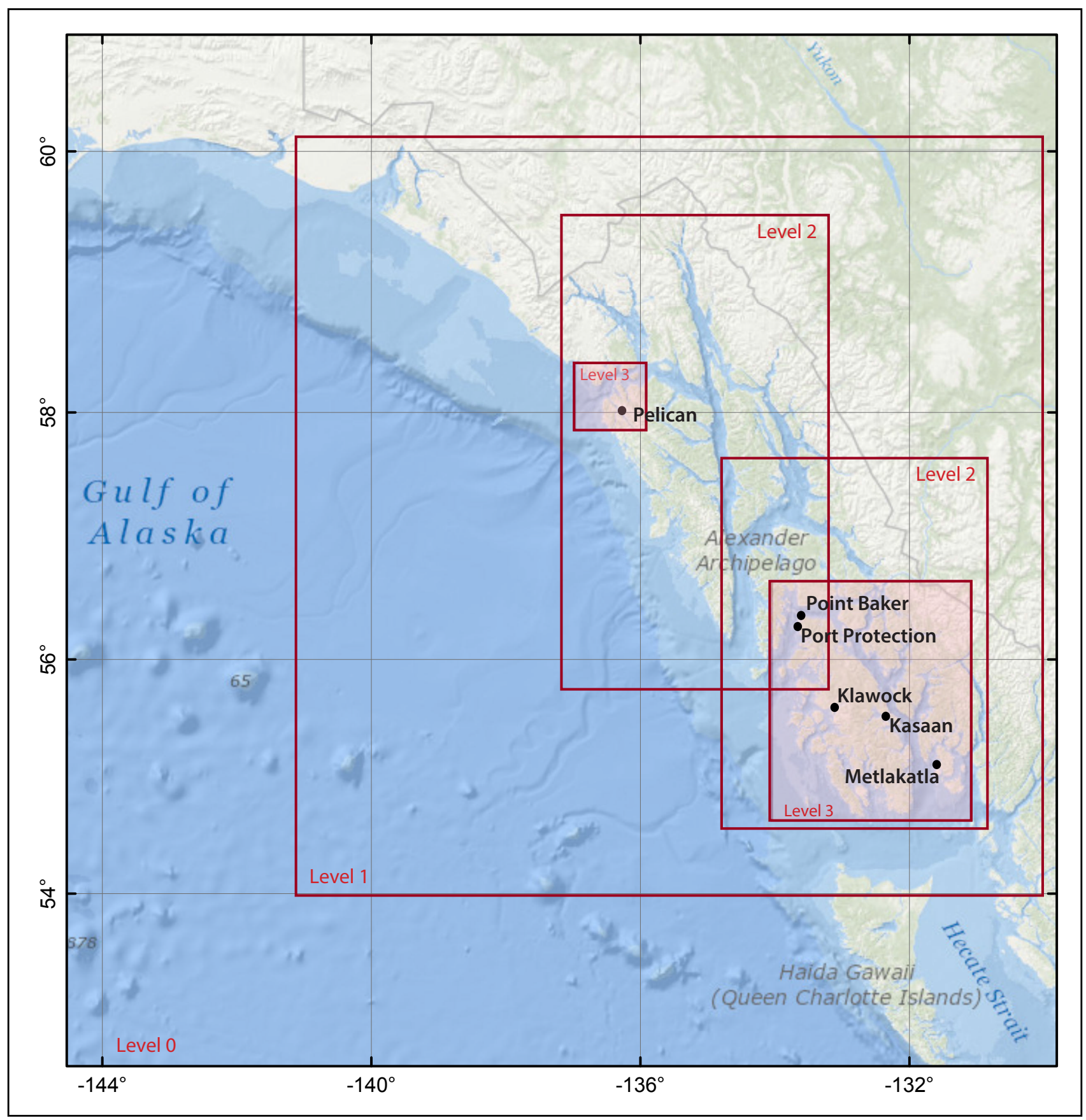

Figure 3. Nested bathymetry/topography grids for numerical modeling of tsunami propagation and runup. The coarsest grid, level 0 , covers the central and northern Pacific Ocean. The location of each embedded grid is marked by a red rectangle. Refer to table 2 for grid parameters. 
$M_{W} 9.3$ event: Extended 1964 rupture (figure $4 \mathrm{~A}$ ).

$M_{W} 9.2$ event: Earthquake in the 1964 rupture area with Tohoku-type slip distribution (figure 4B).

$M_{w} 9.0$ event: The SAFRR tsunami scenario (figure $4 \mathrm{C}$ ).

$M_{W} 9.0$ event: Rupture of the Cascadia subduction zone (figure 4D).
$A M_{W} 9.3$ earthquake that ruptures the aftershock area of the 1964 earthquake and, additionally, the Yakataga-Yakutat (YY) segment of the Alaska-Aleutian megathrust (fig. 1). Vertical displacements in the 1964 rupture zone are based on the coseismic deformation model by Johnson and others (1996). A detailed description of this scenario is provided in Suleimani and others (2013).

$A M_{W} 9.2$ earthquake rupturing the eastern part of the AlaskaAleutian megathrust. The slip is distributed almost uniformly along strike, except for the edges of the rupture, where the slip is tapered. In the downdip direction, the slip is concentrated on the shallow portion of the fault (near the seafloor trench), similar to the Tohoku 2011 earthquake (Ito and others, 2011). Suleimani and others (2013) give a detailed description of a sensitivity study to determine which parts of the eastern Alaska-Aleutian megathrust produce the highest tsunami amplitudes in southeast Alaska.

$A M_{W} 9.0$ earthquake rupturing the Alaska-Aleutian megathrust south of the Alaska Peninsula, west of Kodiak Island in the aftershock zone of the 1938 earthquake (fig. 1). The USGS Science Application for Risk Reduction (SAFRR) project, in collaboration with NOAA and State of California agencies, developed this scenario for a tsunami inundation analysis in California (Ross and others, 2013). In this scenario, greater slip occurs closer to the trench. The earthquake is similar to the Tohoku 2011 event, in which a large amount of slip also occurred between the subducting and overriding plates near the Japan trench (Fujii and others, 2011; Shao and others, 2011).

$A M_{W} 9.0$ earthquake rupturing the Cascadia subduction zone along the British Columbia, Washington, Oregon, and northern California coasts. A recent model by Witter and others (2011) suggests that the slip distribution in the down-dip direction is bell-shaped. In this report, the assumed $\mathrm{M}_{\mathrm{W}} 9.0$ rupture recovers 1,200 years' worth of plate convergence with about $36 \mathrm{~m}$ (118 $\mathrm{ft}$ ) of maximum slip (Witter and others, 2011). 


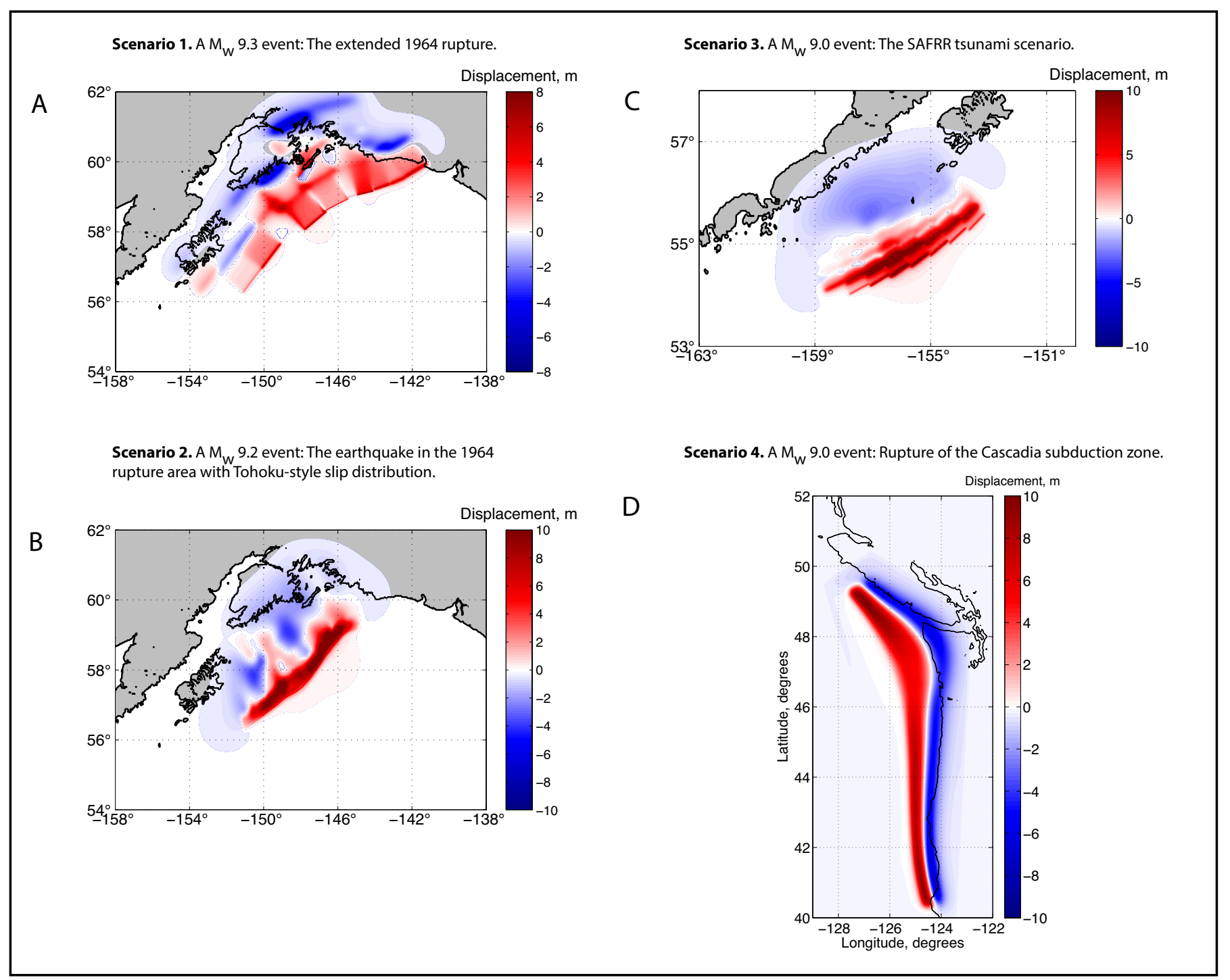

Figure 4. Vertical coseismic deformations corresponding to scenarios $1-4$. Blue areas are coseismic subsidence; red areas are coseismic uplift.

\section{Numerical Model of Tsunami Propagation and Runup}

Our model has been validated through a set of analytical benchmarks and tested against laboratory and field data (NTHMP, 2012; Synolakis and others, 2007). The tsunami scenarios that we calculate in this report are considered to be sufficient to capture the worst-case tsunami event, but there are still an infinite number of possible slip distributions and it is impossible to know which one will occur. Also, there are unforeseen local effects of ground shaking, such as soil compaction and landslides, that could possibly contribute to the extent of tsunami inundation. One of the limitations of the model is that it does not take into account the periodic change of sea level due to tides. We conducted all model runs using bathymetric data that correspond to MHHW. As a result, the elevation of the inundation line could be lower or slightly higher than that given in this report, depending on the tides at the time of a tsunami. A detailed description of the model is given in Nicolsky and others (2011) and the application of the model to tsunami inundation mapping of Alaska coastal communities, including its assumptions and limitations, is described in a number of previous tsunami reports- 
for example, Nicolsky and others (2018) and Suleimani and others (2019).

\section{MODELING RESULTS}

Figures 5 and 6 show the maximum composite tsunami heights for the coastal communities and surrounding waters of Cross Sound and Prince of Wales Island, respectively. In Cross Sound, tsunami amplitudes are relatively small, but the wave heights increase significantly in narrow bays and inlets, including the Lisianski Inlet where the community of Pelican is located (fig. 5). Figure 6 shows maximum composite tsunami heights around Prince of Wales Island. The communities of Kasaan and Metlakatla are better protected from tectonic tsunamis than Klawock, Point Baker, and Port Protection, which are located on the Pacific coast of the island.

Figures 7A-7E show maximum composite tsunami heights for each community. The absolute maximum value of the tsunami height, multiplied by a safety factor of 1.3 , results in a maximum runup height of $1.4 \mathrm{~m}(4.6 \mathrm{ft})$ in Kasaan, $4 \mathrm{~m}$ (13 $\mathrm{ft})$ in Klawock, $1 \mathrm{~m}(3.3 \mathrm{ft})$ in Metlakatla, $5 \mathrm{~m}(16$ $\mathrm{ft})$ in Pelican, $1.3 \mathrm{~m}(4.3 \mathrm{ft})$ in Point Baker, and

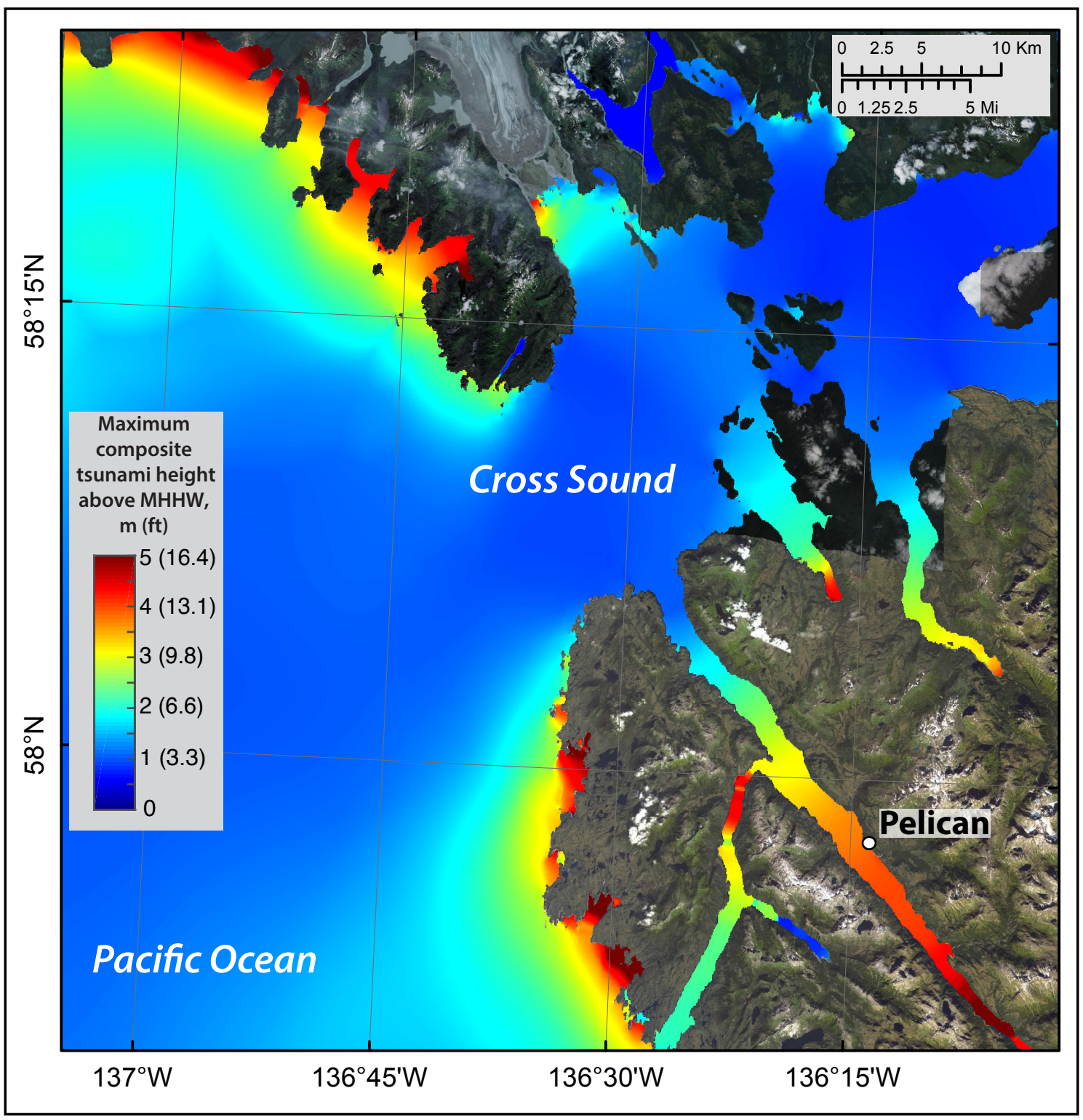

Figure 5. Maximum composite tsunami height from all scenarios in the Cross Sound level 3 grid. 
$2.6 \mathrm{~m}(8.5 \mathrm{ft})$ in Port Protection. We project these values of maximum runup onto land and draw an elevation contour that corresponds to this heightthe boundary of the tsunami hazard zone. The modeling results are summarized in table 3 .

Map sheets 1-6 illustrate the approximate tsunami hazard boundaries for each community.
The maps for Kasaan, Metlakatla, and Point Baker indicate that none of the considered scenarios produce any significant inundation in these communities. However, previous tsunami studies of communities in Southeast Alaska (Suleimani and others, 2015) showed that fords in this region are prone to underwater landslide- and subaerial rock-

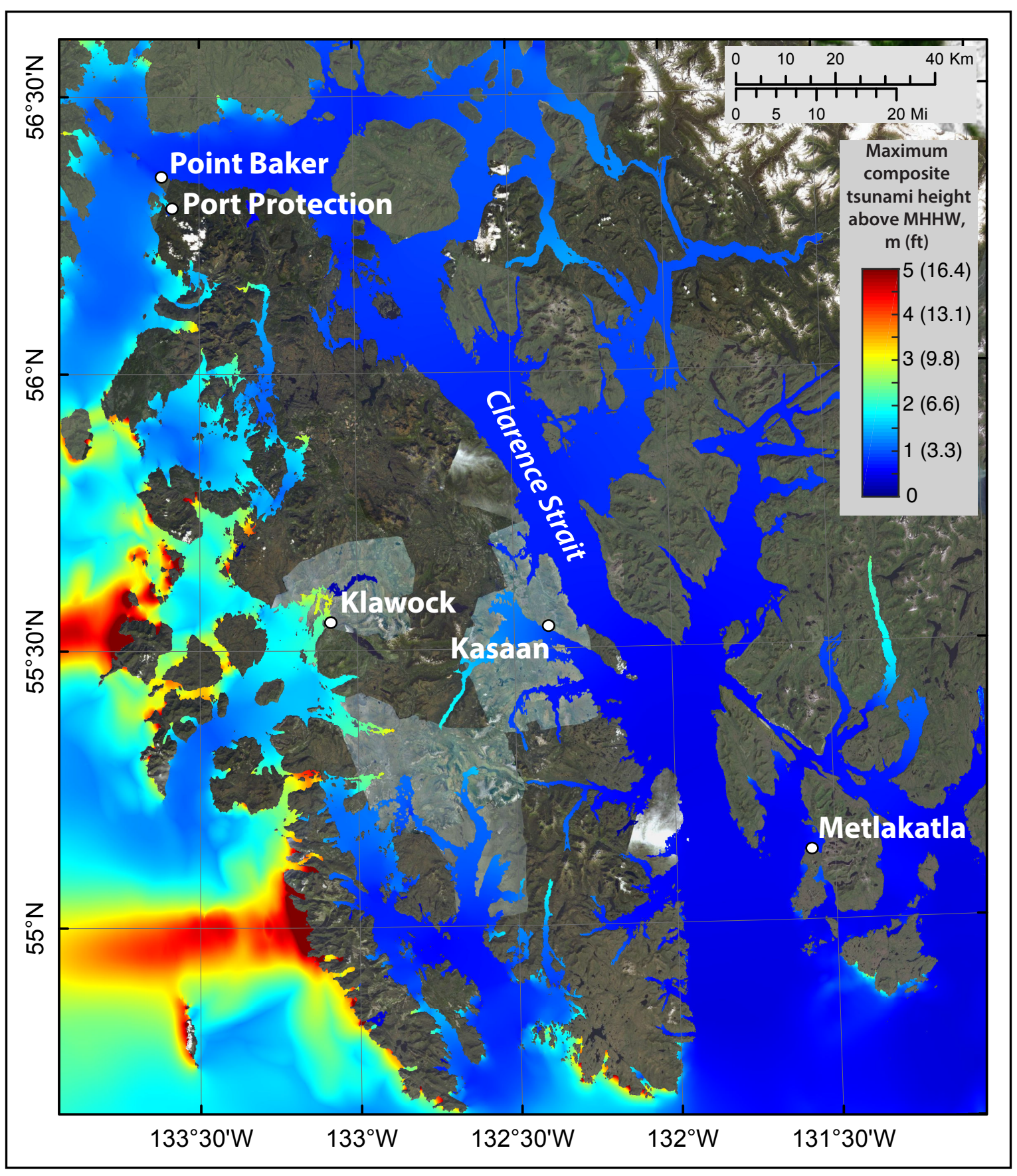

Figure 6. Maximum composite tsunami height from all scenarios in the Prince of Wales level 3 grid. 


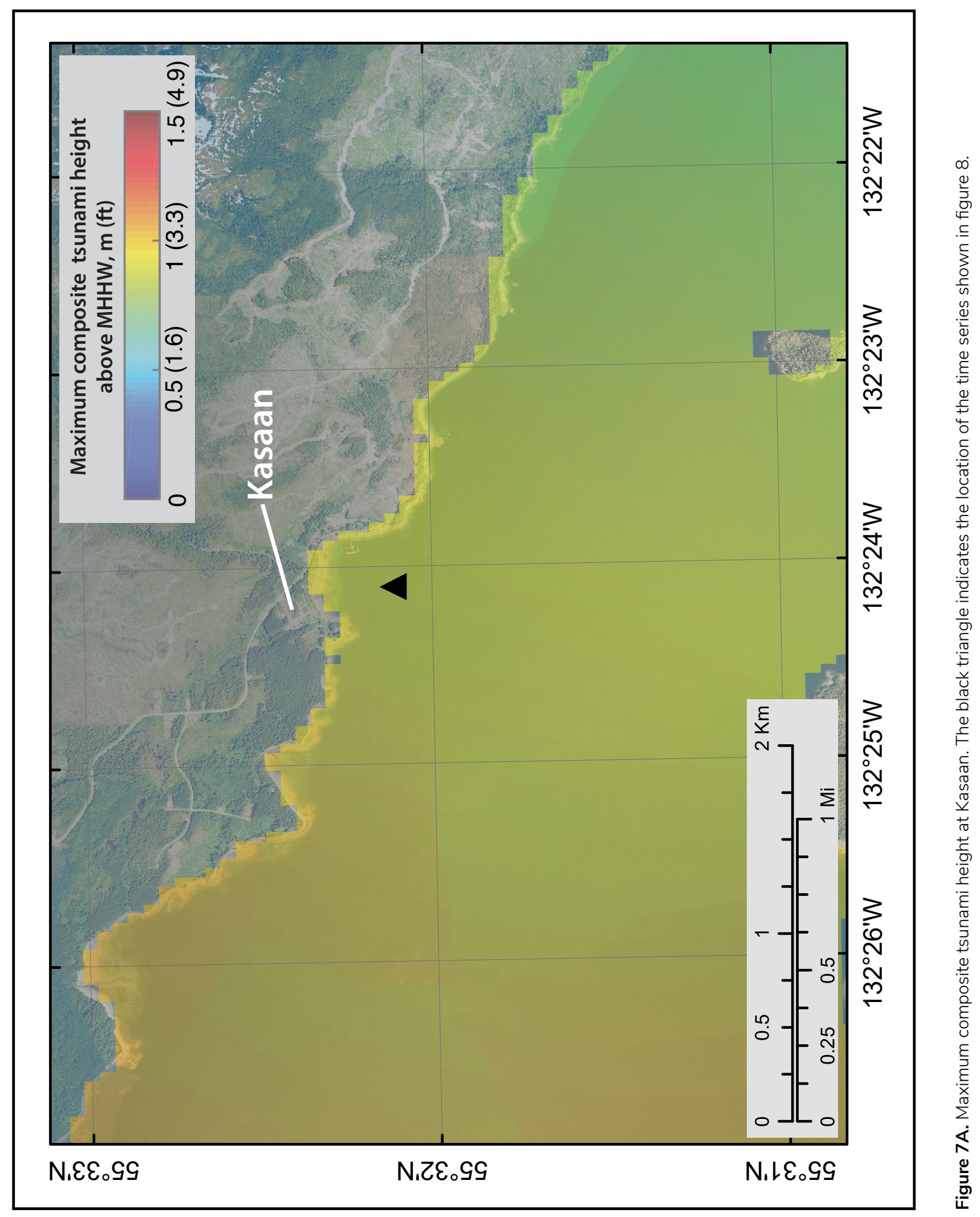




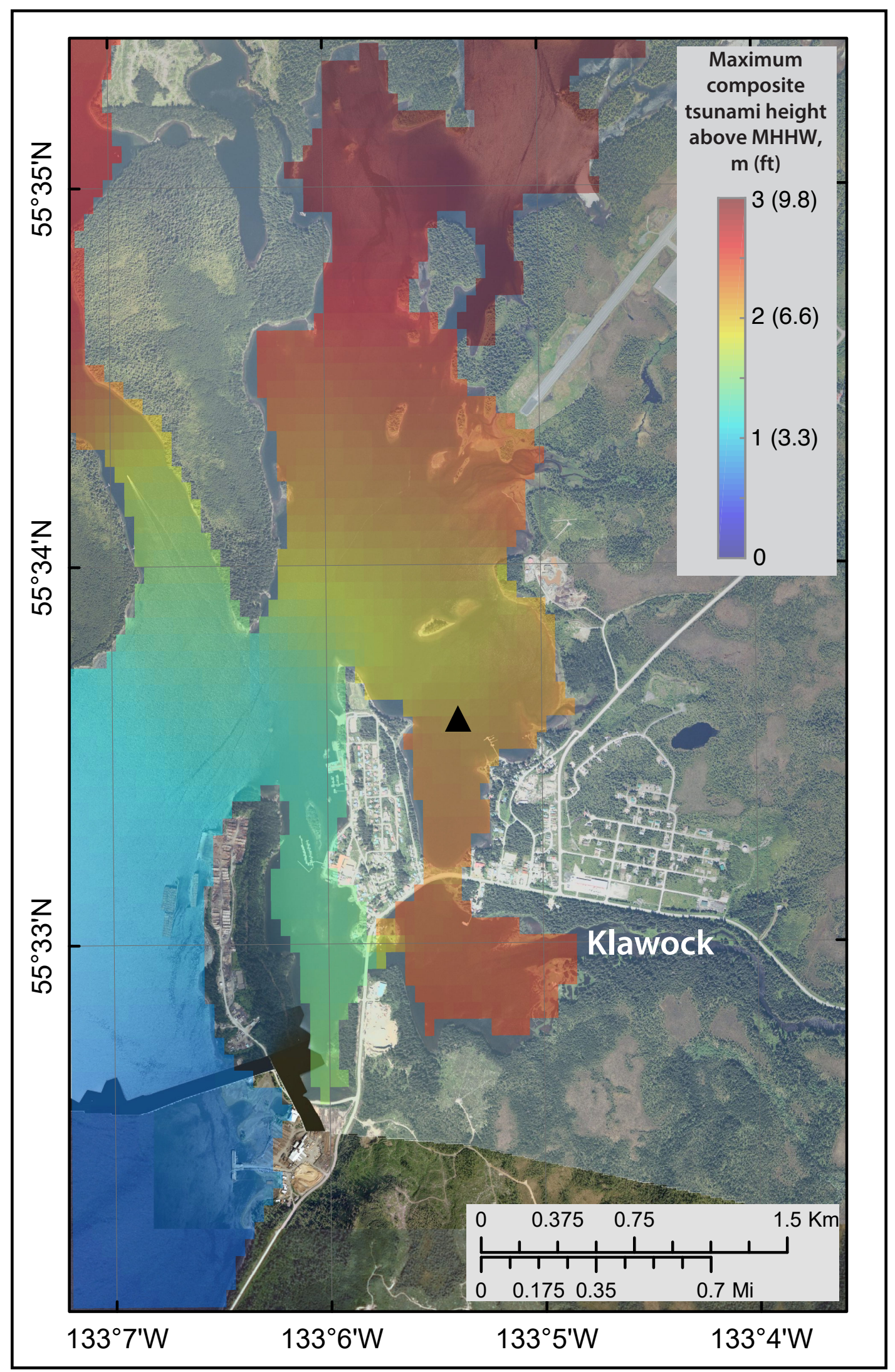

Figure 7B. Maximum composite tsunami height at Klawock. The black triangle indicates the location of the time series shown in figure 8. 


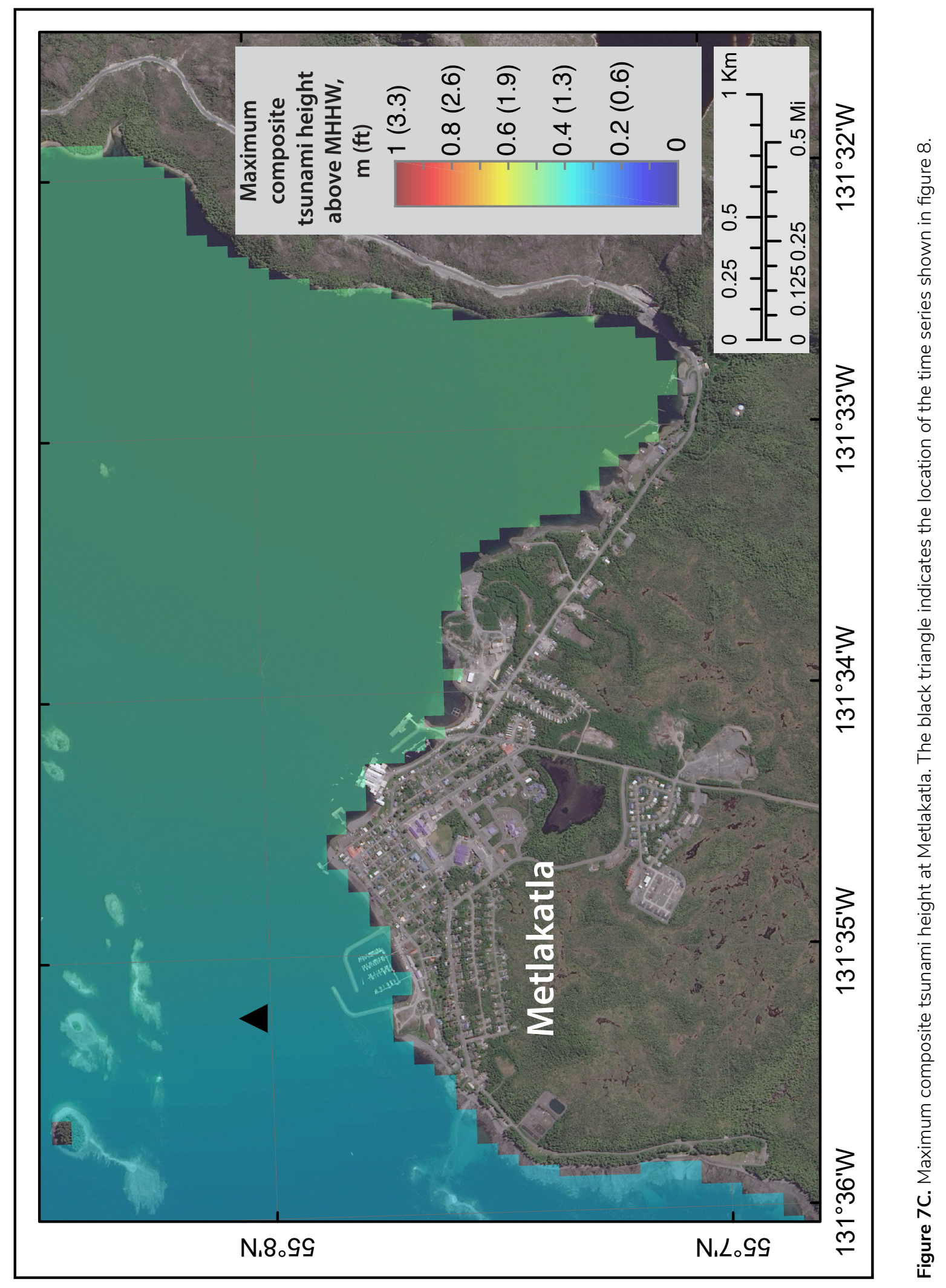




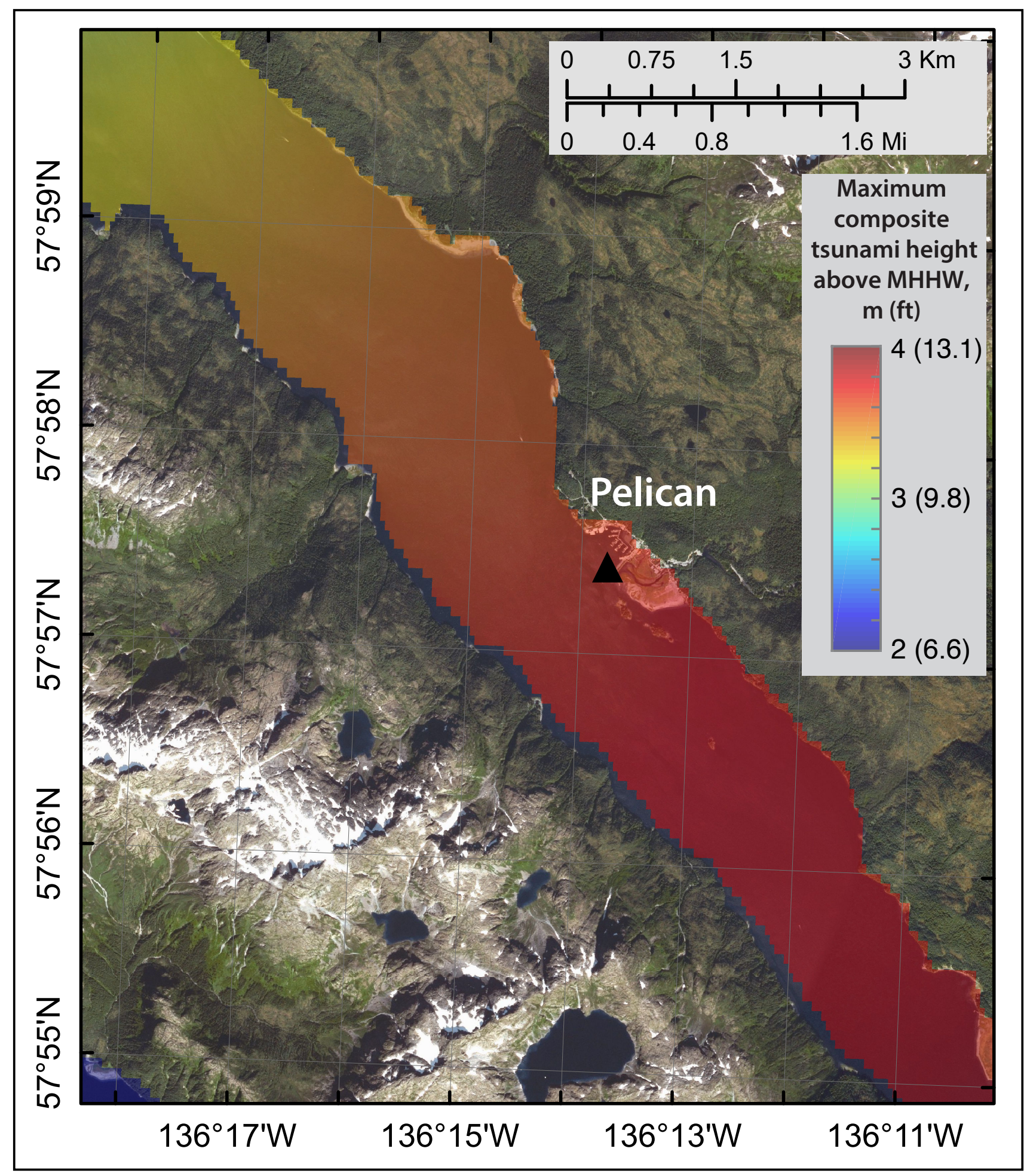

Figure 7D. Maximum composite tsunami height at Pelican. The black triangle indicates the location of the time series shown in figure 8. 
fall-generated tsunamis. However, in this report we do not model tsunamis generated by landslides because there is insufficient data to appropriately constrain landslide sources. These communities should still be prepared.

To help emergency managers assess the tsunami hazard in each community, we supplement the hazard maps with the time series of the modeled water level at a near-shore location in each community. These locations are shown by black triangles in figures 7A-7E. The time series plots are shown in figure 8. Analysis of the time series plots shows that scenario 1 , the extended 1964 rupture, results in the largest tsunami amplitudes at Kasaan and Klawock, while scenario 2, a hypothetical earthquake in the 1964 rupture area with Tohoku-type slip distribution, results in the largest tsunami amplitudes in all other communities. The tsunami amplitudes increase significantly about 4 hours after the arrival of the first wave in Pelican and Kasaan, and about 2 hours after arrival of the first wave in Klawock, which highlights the potential for local amplification effects in bays and inlets where these communities are located.

\section{SUMMARY}

We present model results of earthquake-generated tsunamis in Southeast Alaska for the communities of Kasaan, Klawock, Metlakatla, Pelican, Point Baker, and Port Protection. We numerically model tsunami waves generated by local hypothetical tectonic sources, analyze tsunami wave dynamics in the vicinity of the communities, and develop tsunami-hazard map approx-

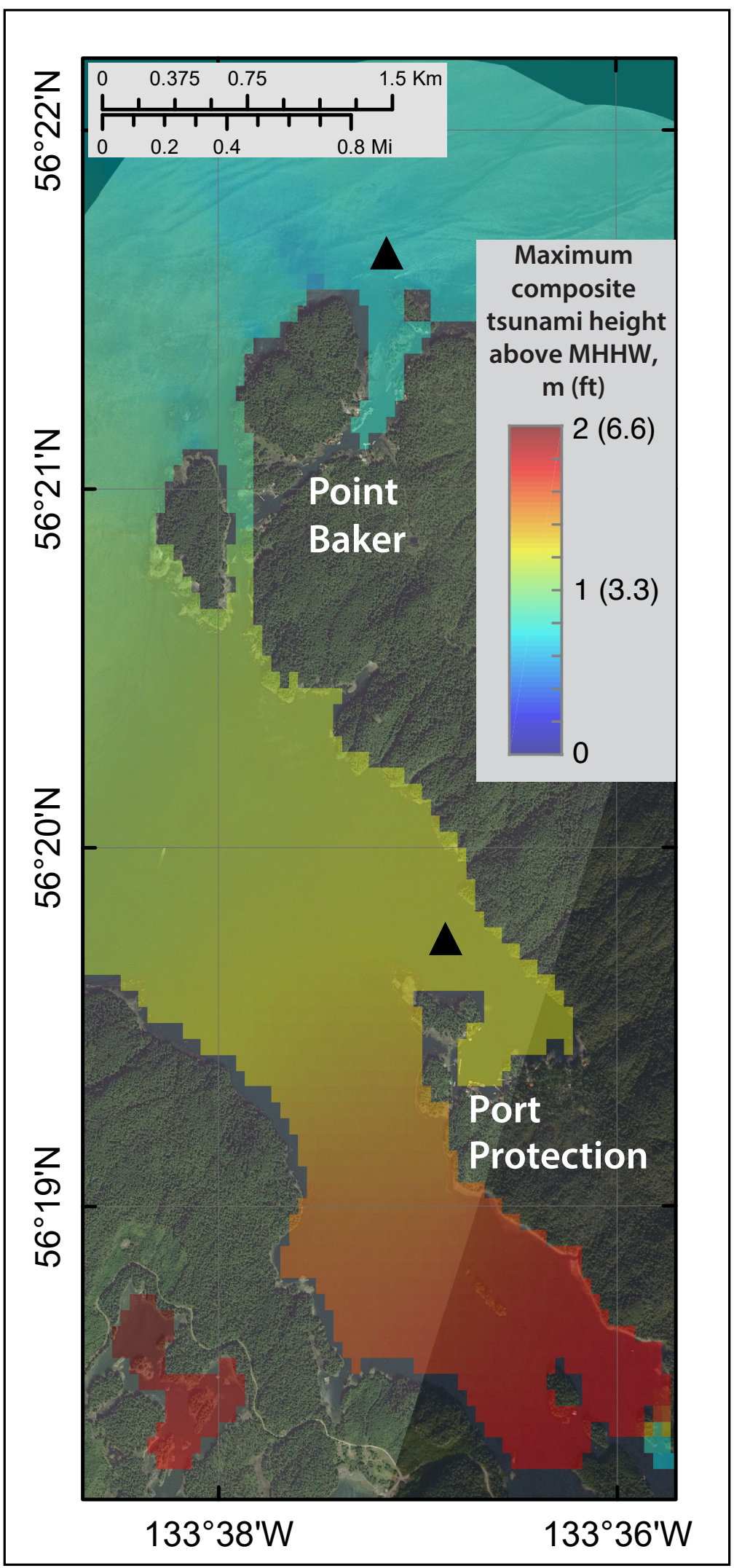

Figure 7E. Maximum composite tsunami height at Point Baker and Port Protection. The black triangles indicate the location of the time series shown in figure 8. 
Table 3. Summary of tsunami modeling results for the Southeast communities.

\begin{tabular}{|l|c|c|c|c|c|}
\hline \multicolumn{1}{|c|}{ Community } & $\begin{array}{c}\text { Maximum } \\
\text { composite } \\
\text { tsunami height }\end{array}$ & $\begin{array}{c}\text { Maximum } \\
\text { assumed runup } \\
\text { height }\end{array}$ & $\begin{array}{c}\text { Composite } \\
\text { tsunami } \\
\text { height }\end{array}$ & $\begin{array}{c}\text { Tsunami } \\
\text { hazard map }\end{array}$ & $\begin{array}{c}\text { Calculated } \\
\text { time series }\end{array}$ \\
\hline Kasaan & $1.1 \mathrm{~m}(3.6 \mathrm{ft})$ & $1.4 \mathrm{~m}(4.6 \mathrm{ft})$ & Figure 7A & Map sheet 1 & Figure $8 \mathrm{~A}$ \\
\hline Klawock & $3 \mathrm{~m}(9.8 \mathrm{ft})$ & $4 \mathrm{~m}(13.1 \mathrm{ft})$ & Figure 7B & Map sheet 2 & Figure 8B \\
\hline Metlakatla & $0.8 \mathrm{~m}(2.6 \mathrm{ft})$ & $1 \mathrm{~m}(3.3 \mathrm{ft})$ & Figure 7C & Map sheet 3 & Figure 8C \\
\hline Pelican & $3.8 \mathrm{~m}(12.5 \mathrm{ft})$ & $5 \mathrm{~m}(16.4 \mathrm{ft})$ & Figure 7D & Map sheet 4 & Figure 8D \\
\hline Point Baker & $1 \mathrm{~m}(3.3 \mathrm{ft})$ & $1.3 \mathrm{~m}(4.3 \mathrm{ft})$ & Figure 7E & Map sheet 5 & Figure 8E \\
\hline Port Protection & $2 \mathrm{~m}(6.6 \mathrm{ft})$ & $2.6 \mathrm{~m}(8.5 \mathrm{ft})$ & Figure 7E & Map sheet 6 & Figure 8F \\
\hline
\end{tabular}

imations. We compute the composite maximum wave height from all considered scenarios and follow the NTHMP guidelines to extrapolate the modeling data on land for estimation of tsunami inundation.

The maximum runup heights are $1.4 \mathrm{~m}(4.6$ $\mathrm{ft})$ in Kasaan, $4 \mathrm{~m}(13.1 \mathrm{ft})$ in Klawock, $1 \mathrm{~m}(3.3$ $\mathrm{ft})$ in Metlakatla, $5 \mathrm{~m}(16.4 \mathrm{ft})$ in Pelican, $1.3 \mathrm{~m}$ $(4.3 \mathrm{ft})$ in Point Baker, and $2.6 \mathrm{~m}(8.5 \mathrm{ft})$ in Port Protection.

The tsunami inundation approximations shown on the tsunami hazard maps have been completed using the best information available and are believed to be accurate; however, their preparation required many assumptions. In this assessment, we estimate the potential tsunami inundation zone based on four significant, scientifically plausible tsunami scenarios. Hence, the modeled tsunami inundation cannot be considered exhaus- tive, but the modeling results are still thought to provide a sound approximation to the potential tsunami inundation zone in each community.

Actual conditions during a tsunami may differ from the scenarios considered here due to variations in the source earthquakes, tides, and coastline infrastructure. These areas of maximum expected inundation are intended to assist in planning tsunami evacuation and response activities. Results are not suitable for land-use regulation or building-code development.

\section{ACKNOWLEDGMENTS}

This project received support from the National Oceanic and Atmospheric Administration (NOAA) under grant awards: NA16NWS4670030, NA17NWS4670006, and NA19NWS4670008 with the State of Alaska's Division of Homeland Security \& Emergency Management. 
A

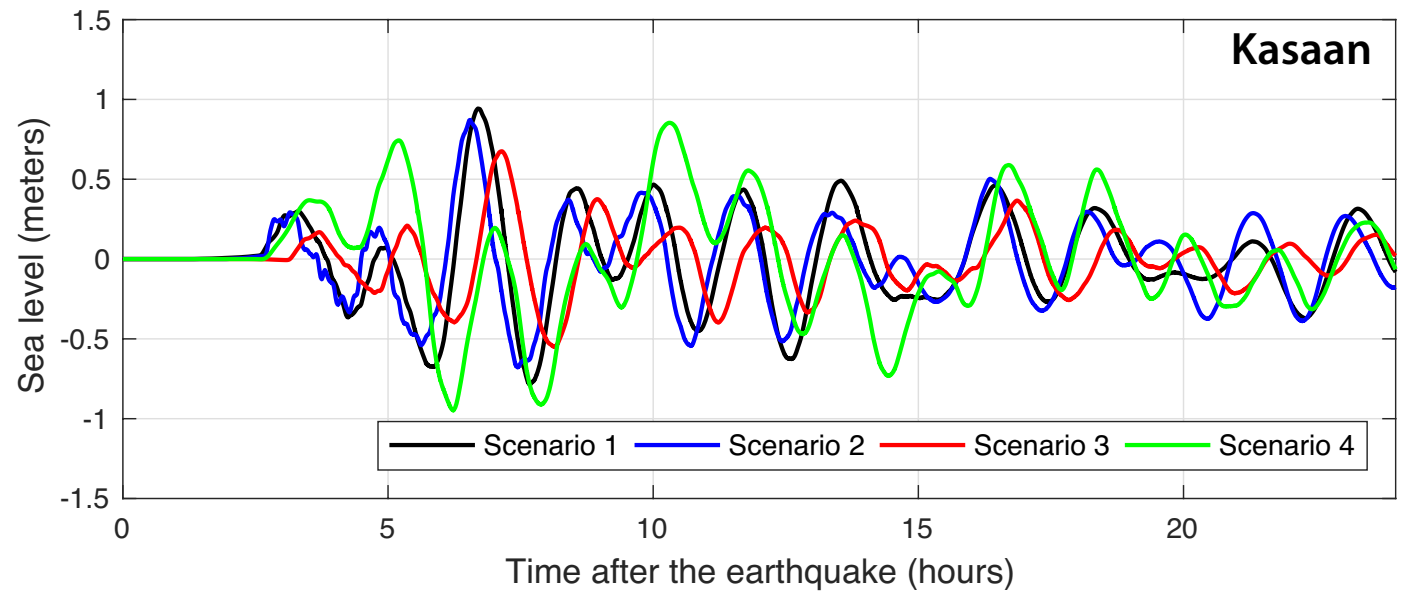

B

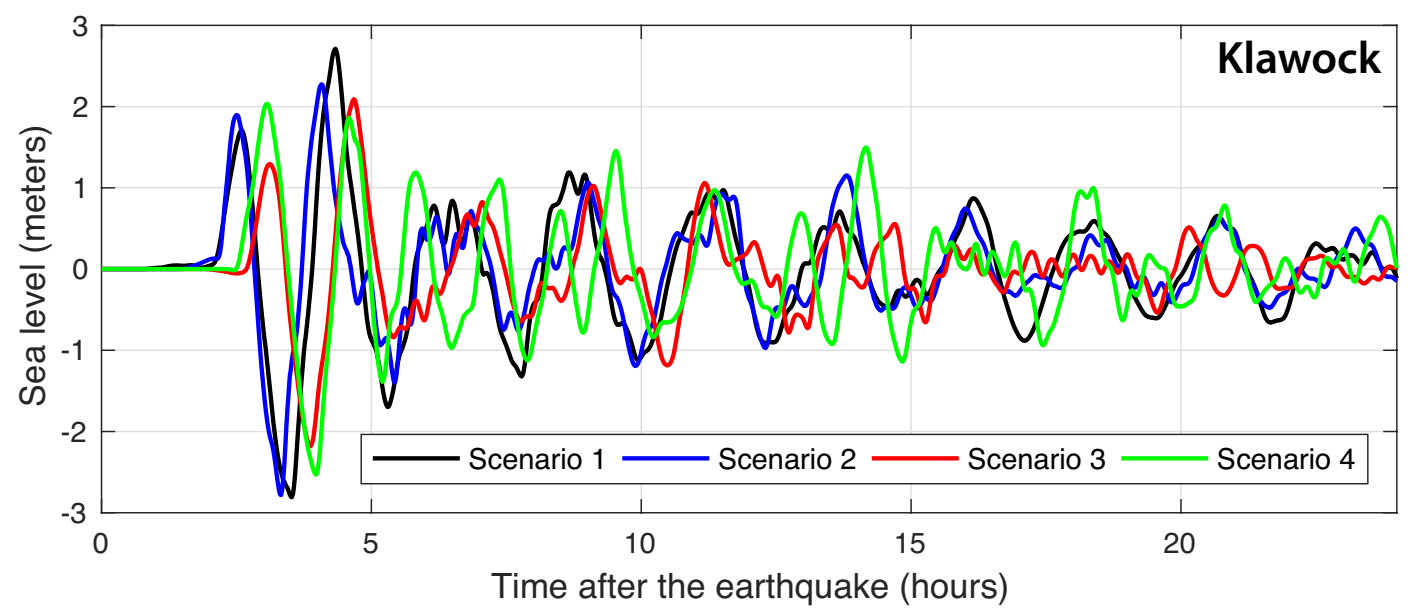

C

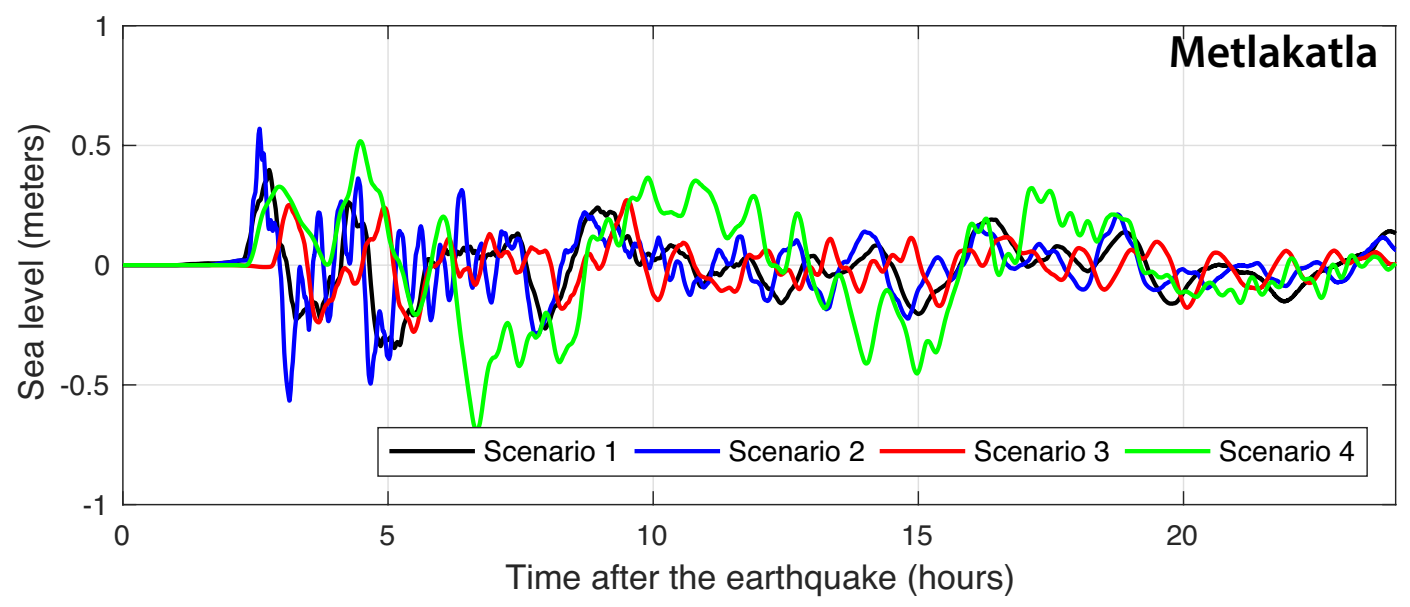

Figure 8. Time series of water level for scenarios 1-4 at (A) Kasaan, (B) Klawock, (C) Metlakatla, (D) Pelican, (E) Point Baker, and (F) Port Protection, calculated at the locations of black triangles in figures 7A-E. 
D

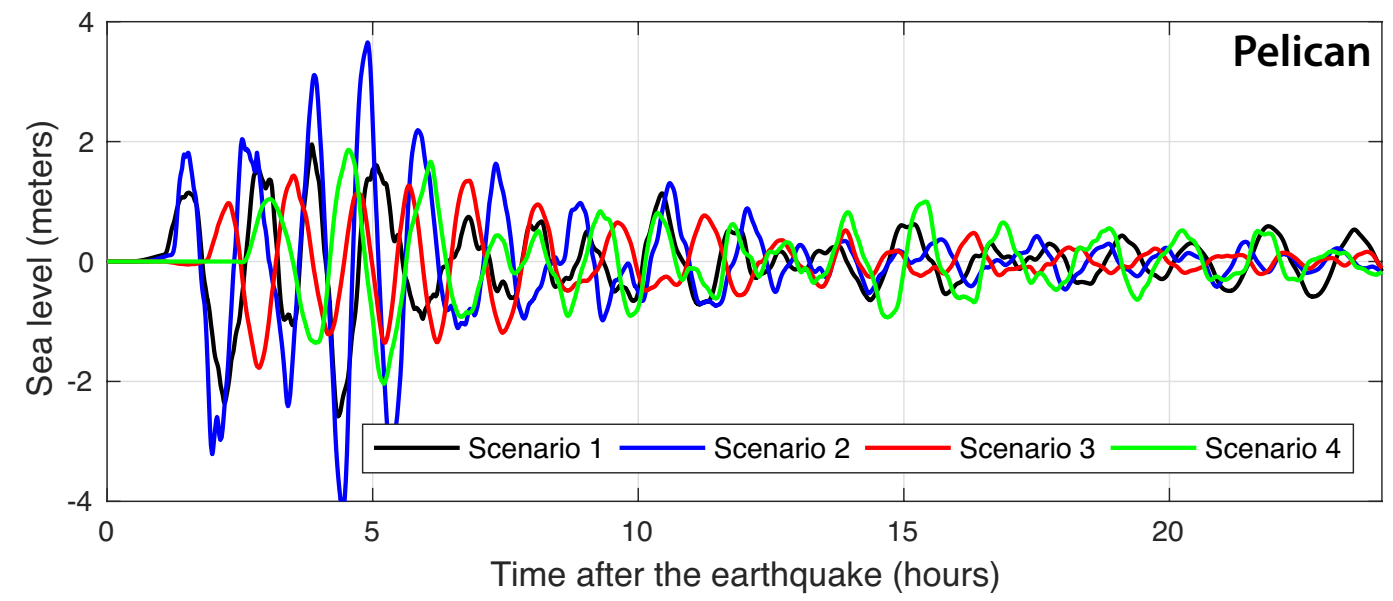

E

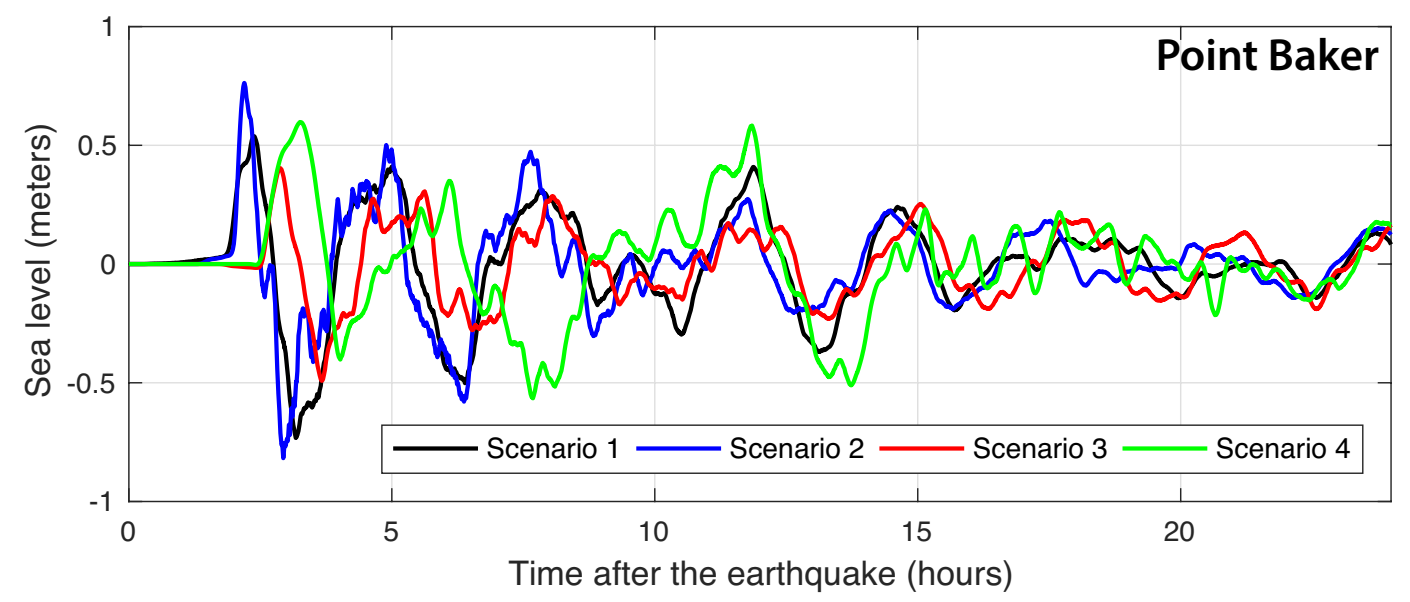

F

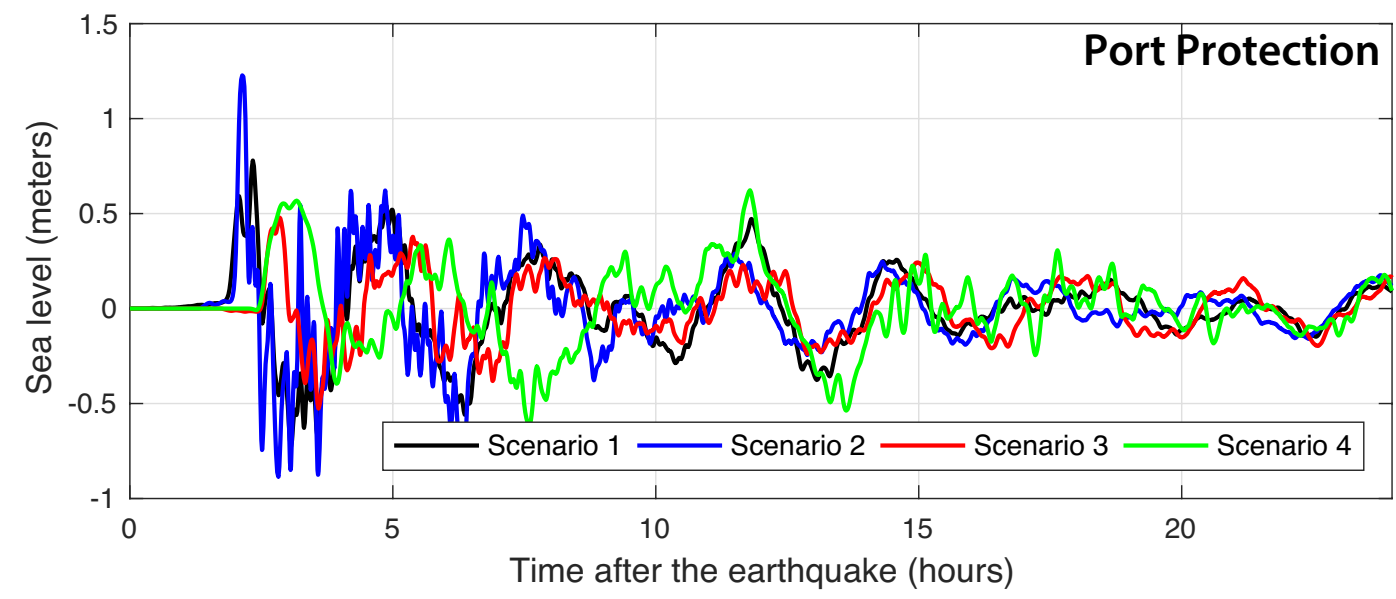

Figure 8, continued. Time series of water level for scenarios 1-4 at (A) Kasaan, (B) Klawock, (C) Metlakatla, (D) Pelican, (E) Point Baker, and (F) Port Protection, calculated at the locations of black triangles in figures 7A-E. 


\section{REFERENCES}

Alaska Department of Commerce, Community and Economic Development, Division of Community and Regional Affairs (DCCED/DCRA), 2013. dcra-cdo-dcced.opendata.arcgis.com/

Caldwell, R.J., Taylor, L.A., Eakins, B.W., Carignan, K.S., and Collins, S.V., 2012, Digital elevation models of Juneau and Southeast AlaskaProcedures, data sources and analysis: National Geophysical Data Center, NOAA Technical Memorandum NESDIS NGDC, p. 53-66.

Carver, G.A., and Plafker, George, 2008, Paleoseismicity and neotectonics of the Aleutian subduction zone-An overview, in Freymueller, J.T., Haeussler, P.J., Wesson, R.L, and Ekström, G., eds., Active tectonics and seismic potential of Alaska: American Geophysical Union Monograph 179, p. 43-63.

Dunbar, P.K., and Weaver, C.S., 2008, U.S. states and territories national tsunami hazard assessment-Historical record and sources for waves: Technical Report, National Oceanic and Atmospheric Administration and U.S. Geological Survey, 59 p. nthmp.tsunami.gov/documents/ Tsunami_Assessment_Final.pdf

Estabrook, C.H., Jacob, K.H., and Sykes, L.R., 1994, Body wave and surface wave analysis of large and great earthquakes along the eastern Aleutian arc, 1923-1993; Implications for future events: Journal of Geophysical Research, v. 99, no. B6, p. 11,643-11,662.

Freymueller, J.T., Woodard, Hilary, Cohen, S.C., Cross, Ryan, Elliott, Julie, Larsen, C.F., Hreinsdóttir, Sigrún, and Zweck, Chris, 2008, Active deformation processes in Alaska, based on 15 years of GPS measurements, in Freymueller, J.T., Haeussler, P.J., Wesson, R.L., Ekström, Göran, Active tectonics and seismic potential of Alaska: American Geophysical Union Geophysical Monograph Series, v. 179, p. 1-42. doi.org/10.1029/GM179

Fujii, Yushiro, Satake, Kenji, Sakai, Shin'ichi, Shinohara, Masanao, and Kanazawa, Toshihiko, 2011, Tsunami source of the 2011 off the Pacific coast of Tohoku earthquake: Earth Planets Space, v. 63, p. 815-820. doi.org/10.5047/ eps.2011.06.010

Geist, E.L., and Parsons, Tom, 2006, Probabilistic analysis of tsunami hazards: Natural Hazards. v. 37, no. 3, p. 277-314. dx.doi. org/10.1007/ s11069-005-4646-z

Ito, Yoshihiro, Tsuji, Takeshi, Osada, Yukihito, Kido, Motoyuki, Inazu, Daisuke, Hayashi, Yutaka, Tsushima, Hiroaki, Hino, Ryota, and Fujimoto, Hiromi, 2011, Frontal wedge deformation near the source region of the 2011 Tohoku-Oki earthquake: Geophysical Research Letters, v. 38, no. 7. doi.org/10.1029/2011GL048355

James, Thomas, Rogers, Garry, Cassidy, John, Dragert, Herb, Hyndman, Roy, Leonard, Lucinda, Nykolaishen, Lisa, Riedel, Michael, Schmidt, Michael, and Wang, Kelin, 2013, Field studies target 2012 Haida Gwaii Earthquake: EOS v. 94, no. 22, p. 197-198.

Johnson, J.M., Satake, Kenji, Holdahl, S.R., and Sauber, Jeanne, 1996, The 1964 Prince William Sound earthquake-Joint inversion of tsunami waveforms and geodetic data: Journal of Geophysical Research, v. 101, no. B1, p. 523532. doi.org/10.1029/95JB02806

Johnson, J.M., Tanioka, Yuichiro, Ruff, L.J., Satake, Kenji, Kanamori, Hiroo, and Sykes, L.R., 1994, The 1957 great Aleutian earthquake, Pure and Applied Geophysics, v. 142, no. 1, p. 3-28. doi. org/10.1007/BF00875966

Kanamori, Hiroo, 1970, The Alaska earthquake of 1964-Radiation of long-period surface waves and source mechanism: Journal of Geophysical Research, v. 75, no. 26, p. 5,029-5,040. doi. org/10.1029/JB075i026p05029

Lay, Thorne, Ye, Lingling, Kanamori, Hiroo, Yamazaki, Yoshiki, Cheung, Kwok Fai, Kwong, Kevin, and Koper, K., 2013, The October 28, 2012 Mw7.8 Haida Gwaii underthrusting earthquake and tsunami-Slip partitioning along the Queen Charlotte fault transpressional plate boundary: Earth and Planetary Science Letters, 375 , p. 57-70.

Lander, J.F., 1996, Tsunamis affecting Alaska, 17371996: Boulder, CO, NOAA National Geophysical Data Center (NGDC), Key to Geophysical Research Documentation, v. 31, 195 p. 
Leonard, L.J., and Bednarski, J.M., 2015, The preservation potential of coastal coseismic and tsunami evidence observed following the 2012 $\mathrm{M}_{\mathrm{W}} 7.8$ Haida Gwaii thrust earthquake, in 2012 Haida Gwaii and 2013 Craig earthquakes at the Pacific North America plate boundary (British Columbia and Alaska), Bulletin of the Seismological Society of America, v. 105, no. 2B, p. 1,280-1,289. doi.org/10.1785/0120140193

Lim, Elliot, Eakins, B.W., and Wigley, Rochelle, 2011, Coastal relief model of southern AlaskaProcedures, data sources and analysis: National Oceanic and Atmospheric Administration (NOAA) Technical Memorandum NESDIS NGDC-43, 22 p. docs.lib.noaa.gov/noaa documents/NESDIS/NGDC/TM/NOAA_ TM_NESDIS_NGDC_43.pdf

Lopez, A.M., and Okal, E.A., 2006, A seismological reassessment of the source of the 1946 Aleutian 'tsunami' earthquake: Geophysical Journal International, v. 165 , no. 3, p. 835-849. doi. org/10.1111/j.1365-246X.2006.02899.x

Miller, D.J., 1960, The Alaska earthquake of July 10, 1958: Giant wave in Lituya Bay: Bulletin of the Seismological Society of America, v. 50, no. 2, p. 253-266.

National Centers for Environmental Information (NCEI)/World Data Service (WDS), in progress, Global historical tsunami database at NGDC, 2100 BC to present (interactive map): National Geophysical Data Center, NOAA. doi. org/10.7289/V5PN93H7

National Geophysical Data Center (NGDC), 2006, 2-minute Gridded Global Relief Data (ETOPO2) v2: National Geophysical Data Center (NGDC), National Oceanic and Atmospheric Administration (NOAA). doi.org/10.7289/V5J1012Q

National Tsunami Hazard Mapping Program (NTHMP), 2010, Guidelines and best practices for tsunami inundation modeling for evacuation planning: National Oceanic and Atmospheric Administration (NOAA), NTHMP Mapping \& Modeling Subcommittee.

2012, Proceedings and results of the 2011 NTHMP Model Benchmarking Workshop:
Boulder, CO, U.S. Department of Commerce/ NOAA/NTHMP, NOAA Special Report, 436 p. nthmp.tsunami.gov

National Tsunami Warning Center (NOAA/NWS), n.d., Tsunami of 5 January, 2013 (WSW Craig, Alaska): National Oceanic and Atmospheric Administration (NOAA). ntwc.ncep.noaa.gov/ previous.events/?p=01-05-13

Nicolsky, D.J., Suleimani, E.N., Haeussler, P.J., Ryan, H.F., Koehler, R.D., Combellick, R.A., and Hansen, R.A., 2013, Tsunami inundation maps of Port Valdez, Alaska: Alaska Division of Geological \& Geophysical Surveys Report of Investigation 2013-1, 77 p., 1 sheet, scale 1:12,500. doi.org/10.14509/25055

Nicolsky, D.J., Suleimani, E.N., and Hansen, R.A., 2011, Validation and verification of a numerical model for tsunami propagation and runup: Pure and Applied Geophysics, v. 168, no. 6, p. 1,1991,222. doi.org/10.1007/s00024-010-0231-9

Nicolsky, D.J., Suleimani, E.N., and Koehler, R.D., 2014, Tsunami inundation maps of Cordova and Tatitlek, Alaska: Alaska Division of Geological \& Geophysical Surveys Report of Investigation 2014-1, 49 p., 2 sheets. doi.org/10.14509/27241

Nicolsky, D.J., Suleimani, E.N., and Salisbury, J.B., 2018, Tsunami inundation maps for Skagway and Haines, Alaska: Alaska Division of Geological \& Geophysical Surveys Report of Investigation 2018-2, 69 p., 3 sheets. doi.org/10.14509/30029 Page, R.A., 1973, The Sitka, Alaska earthquake of 1972: U.S. Geological Survey Earthquake Information Bulletin, v. 5, no. 5, p. 4-9.

Ross, S.L., Jones, L.M., Miller, Kevin, Porter, K.A., Wein, Anne, Wilson, R.I., Bahng, Bohyun, Barberopoulou, Aggeliki, Borrero, J.C., Brosnan, D.M., Bwarie, J.T., Geist, E.L., Johnson, L.A., Kirby, S.H., and others, 2013, SAFRR (Science Application for Risk Reduction) Tsunami Scenario-Executive Summary and Introduction: U.S. Geological Survey Open-File Report 20131170-A, in Ross, S.L., and Jones, L.M., eds., The SAFRR (Science Application for Risk Reduction) Tsunami Scenario: U.S. Geological Survey OpenFile Report 2013-1170, 17 p. pubs.usgs.gov/ of/2013/1170/a/ 
Shao, Guangfu, Li, Xiangyu, Ji, Chen, and Maeda, Takahiro, 2011, Focal mechanism and slip history of $2011 \mathrm{M}_{\mathrm{W}} 9.1$ off the Pacific coast of Tohoku earthquake, constrained with teleseismic body and surface waves: Earth Planets Space, v. 63, no. 7, p. 559-564. doi.org/10.5047/eps.2011.06.028

Suleimani, E.N., Nicolsky, D.J., and Koehler, R.D., 2013, Tsunami inundation maps of Sitka, Alaska: Alaska Division of Geological \& Geophysical Surveys Report of Investigation 2013-3, 76 p., 1 sheet, scale 1:12,500. doi.org/10.14509/26671

2015, Tsunami inundation maps of Elfin Cove, Gustavus, and Hoonah, Alaska: Alaska Division of Geological \& Geophysical Surveys Report of Investigation 2015-1, 79 p., 3 sheets. doi.org/10.14509/29404

-2016, Tsunami inundation maps for Yakutat, Alaska: Alaska Division of Geological \& Geophysical Surveys Report of Investigation 2016-2, 47 p., 1 sheet, scale 1:10,000. doi. org/10.14509/29577

Suleimani, E.N., Nicolsky, D.J., Koehler, R.D., and Salisbury, J.B., 2018, Regional tsunami hazard assessment for Andreanof Islands, Alaska: Alaska Division of Geological \& Geophysical Surveys Report of Investigation 2017-2, 19 p., 2 sheets. doi.org/10.14509/29704

Suleimani, E.N., Nicolsky, D.J., and Salisbury, J.B., 2019, Updated tsunami inundation maps for Homer and Seldovia, Alaska: Alaska Division of Geological \& Geophysical Surveys Report of Investigation $2018-5$ v. 2, 97 p., 11 sheets. doi. org/10.14509/30095

Sykes, L.R., 1971, Aftershock zones of great earthquakes, seismicity gaps, and earthquake prediction for Alaska and the Aleutians: Journal of Geophysical Research, v. 75, p. 8,021-8,041.

Synolakis, C.E., Bernard, E.N., Titov, V. V., Kânoğlu, U., and González, F.I., 2007, Standards, criteria, and procedures for NOAA evaluation of tsunami numerical models: Seattle, Washington, NOAA/ Pacific Marine Environmental Laboratory, Technical Memorandum OAR PMEL-135, 55 p. Tocher, Don, 1960, The Alaska earthquake of July 10, 1958: Movement on the Fairweather fault and field investigation of southern epicentral region: Bulletin of the Seismological Society of America, v. 50, no. 2, p. 267-292.

Witter, R.C., Zhang, Yinglong, Wang, Kelin, Priest, G.R., Goldfinger, Chris, Stimely, L.L., English, J.T., and Ferro, P.A., 2011, Simulating tsunami inundation at Bandon, Coos County, Oregon, using hypothetical Cascadia and Alaska earthquake scenarios: Oregon Department of Geology and Mineral Industries Special Paper 43, 57 p.

Wu, F.T., and Kanamori, Hiroo, 1973, Source mechanism of February 4, 1965, Rat Island earthquake: Journal of Geophysical Research, v. 78 , no. 26, p. 6,082-6,092. 